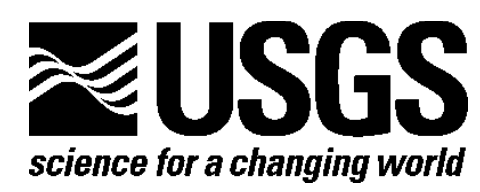

\title{
Water-Level and Wave Measurements in the Chandeleur Islands, Louisiana, 2012 and 2013
}

By Patrick J. Dickhudt, Christopher R. Sherwood, and Nancy T. Dewitt

Open-File Report 2014-1246

U.S. Department of the Interior

U.S. Geological Survey 


\section{U.S. Department of the Interior Sally Jewell, Secretary}

\section{U.S. Geological Survey Suzette Kimball, Acting Director}

U.S. Geological Survey, Reston, Virginia: 2015

For more information on the USGS-the Federal source for science about the Earth, its natural and living resources, natural hazards, and the environment-visit http://uww.usgs.gov or call 1-888-ASK-USGS (1-888-275-8747)

For an overview of USGS information products, including maps, imagery, and publications, visit $h$ ttp://huw.usgs.gov/pubprod

To order this and other USGS information products, visit http://store.usgs.gov

Any use of trade, firm, or product names is for descriptive purposes only and does not imply endorsement by the U.S. Government.

Although this information product, for the most part, is in the public domain, it also may contain copyrighted materials as noted in the text. Permission to reproduce copyrighted items must be secured from the copyright owner.

Suggested citation:

Dickhudt, P.J., Sherwood, C.R., and Dewitt, N.T., 2015, Water-level and wave measurements in the Chandeleur Islands, Louisiana, 2012 and 2013: U.S. Geological Survey Open-File Report 2014-1246, 49 p., http://dx.doi.org/10.3133/ofr20141246. 


\section{Acknowledgments}

The authors thank the captains and crews of the Skipper, Pelican, and Southern $V$ for safe transport to and from the field sites and logistical assistance. The authors thank the following USGS personnel: Kyle Kelso and B.J. Reynolds for their assistance in deploying and recovering gear and surveying the sensor elevations, and Kristy Guy for making site maps. 



\section{Contents}

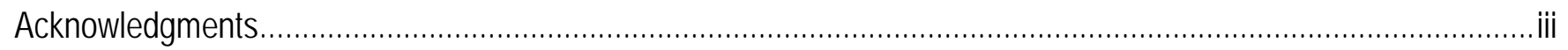

Abstract …… - w w

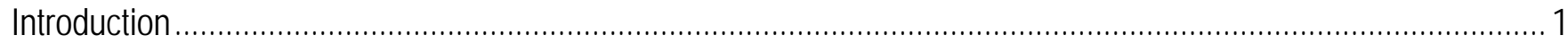

Instrumentation

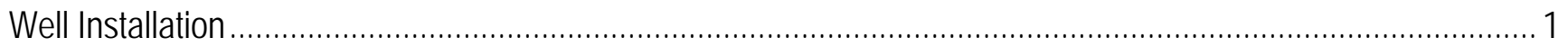

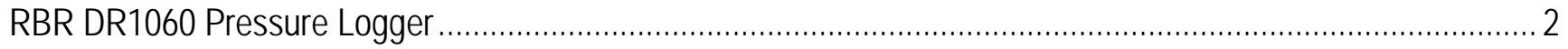

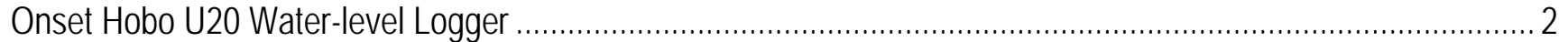

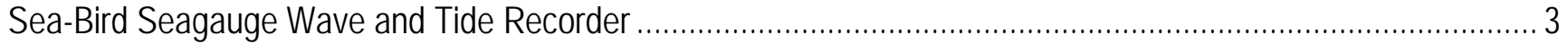

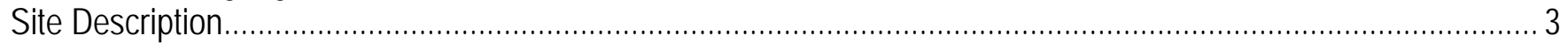

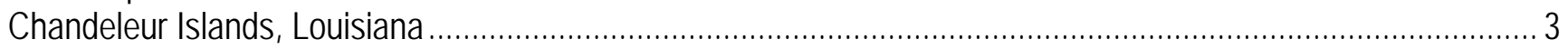

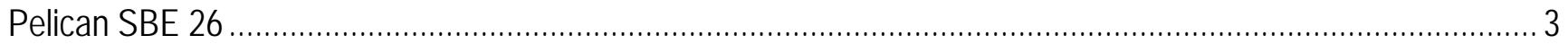

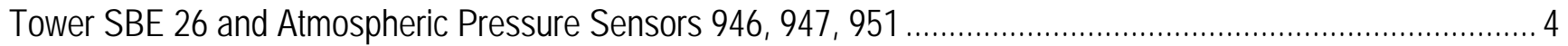

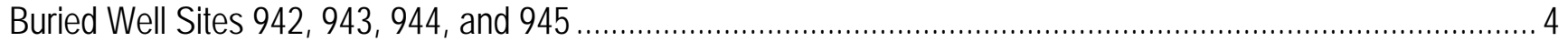

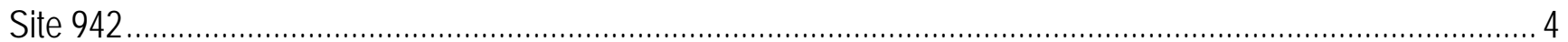

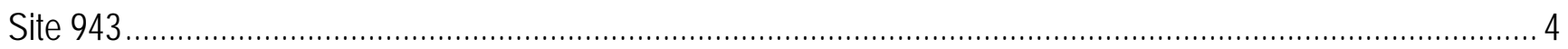

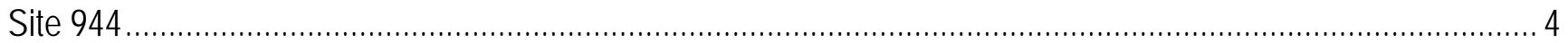

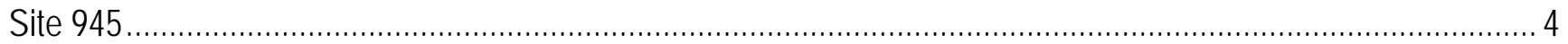

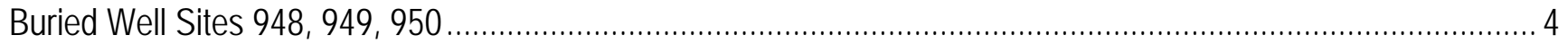

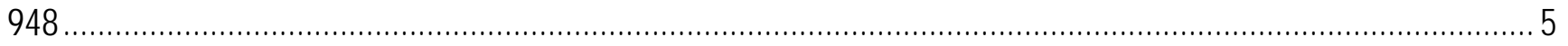

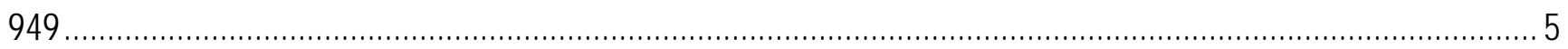

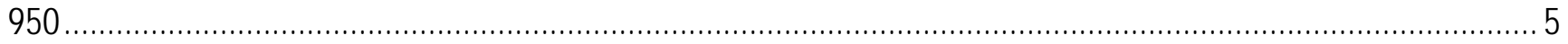

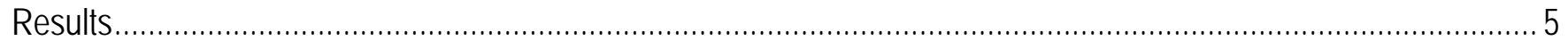

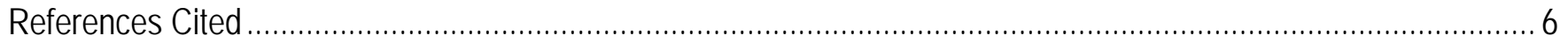

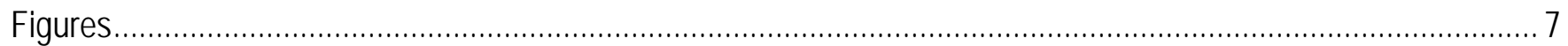

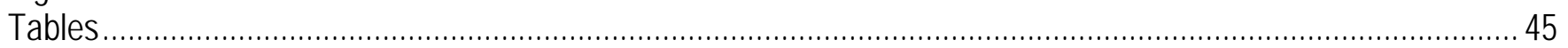

\section{Figures}

1. Maps showing, at increasingly greater scales, the study area and locations of sensors used to monitor atmospheric pressure, water level, and waves in the Chandeleur Islands, Louisiana, during 2012 and 2013

2. Photographs illustrating the procedure for installing a buried well

3. Photographs of $A$, USGS scientists Nancy Dewitt and Kyle Kelso installing the Global Positioning System (GPS) base station and $B$, Nancy Dewitt surveying a well with the GPS rover (after installation and prior to burial) to provide precise information about the location and elevation of the buried pressure sensor.

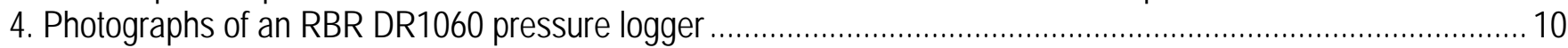

5. Photograph of an Onset Hobo U20 pressure logger and threaded stainless-steel rod..................................... 11

6. Photograph of Onset Hobo U2O atmospheric pressure sensor being mounted on tower by Patrick Dickhudt and

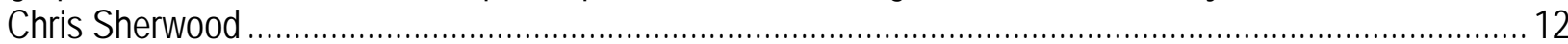

7. Photograph of Sea-Bird SBE 26 wave and water-level sensor after being recovered from tower by USGS

scientists B.J. Reynolds (pictured) and Kyle Kelso ..........................................................................
8. Portion of atmospheric pressure time series from National Oceanic and Atmospheric Administration (National Data Buoy Center) station PTBM6 and Onset Hobo U20 pressure sensors on Tower site, Chandeleur Islands, Louisiana, 2012 to 2013 
9. Atmospheric pressure and temperature time series from an Onset Hobo $\mathrm{U} 20$ atmospheric pressure sensor mounted on the tower at Site 946, Chandeleur Islands, Louisiana, from July 11 through September 7, 201215

10. Atmospheric pressure and temperature time series from an Onset Hobo U20 atmospheric pressure sensor mounted on the tower at Site 947, Chandeleur Islands, Louisiana, from September 7, 2012 to January 31, 2013

11. Atmospheric pressure and temperature time series from an Onset Hobo U20 atmospheric pressure sensor mounted on the tower at Site 951, Chandeleur Islands, Louisiana, from February 1 through July 18, 201317

12. Water level time series from an RBR DR1060 pressure logger mounted in a buried well at Site 942, Chandeleur Islands, Louisiana, from July 10 through September 7, 2012. 18

13. Water level time series from an RBR DR1060 pressure logger mounted in a buried well at Site 943 Chandeleur Islands, Louisiana, from July 10 through September 7, 2012.

14. Water level time series from an RBR DR1060 pressure logger mounted in a buried well at Site 948 , Chandeleur Islands, Louisiana, from February 1 through July 16, 2013

15. Water level time series from an Onset Hobo U20 pressure logger mounted in a buried well at Site 949 Chandeleur Islands, Louisiana, from February 1 through July 16, 2013.

16. Water level time series from an RBR DR1060 pressure logger mounted in a buried well at Site 950, Chandeleur Islands, Louisiana, from February 1 through March 15, 2013 ......................................................... 22

17. Water level and temperature time series from a Sea-Bird SBE 26 deployed at the Pelican site in the Chandeleur Islands, Louisiana, from February 28, 2012, to June 20, 2012 …................................................. 23

18. Wave statistics and sensor depth time series from a Sea-Bird SBE 26 deployed at the Pelican site in the Chandeleur Islands, Louisiana, from February 28, 2012, to June 20, 2012 ....................................... 24

19. Water level and temperature time series from a Sea-Bird SBE 26 deployed at the Pelican site in the Chandeleur Islands, Louisiana, from July 11, 2012, to September 6, 2012

20. Wave statistics and time series of sensor depth relative to sea surface from a Sea-Bird SBE 26 deployed at the Pelican site in the Chandeleur Islands, Louisiana, from July 11, 2012, to September 6, 2012 ................... 26

21. Water level and temperature time series from a Sea-Bird SBE 26 deployed at the Pelican site in the Chandeleur Islands, Louisiana, from September 6, 2012, to December 28, $2012 \ldots \ldots \ldots \ldots \ldots \ldots \ldots \ldots \ldots \ldots \ldots \ldots \ldots \ldots \ldots \ldots \ldots \ldots \ldots . . .27$

22. Wave statistics and time series of sensor depth relative to sea surface from a Sea-Bird SBE 26 deployed at the Pelican site in the Chandeleur Islands, Louisiana, from September 6, 2012, to December 28, 2012 .......... 28

23. Water level and temperature time series from a Sea-Bird SBE 26 deployed at the Pelican site in the Chandeleur Islands, Louisiana, from February 1, 2013, to April 28, 2013 29

24. Wave statistics and time series of sensor depth relative to sea surface from a Sea-Bird SBE 26 deployed at the Pelican site in the Chandeleur Islands, Louisiana, from February 1, 2013, to April 28, 2013.

25. Water level and temperature time series from a Sea-Bird SBE 26 deployed at the Pelican site in the Chandeleur Islands, Louisiana, from April 28, 2013, to July 16, 2013.

26. Wave statistics and time series of sensor depth relative to sea surface from a Sea-Bird SBE 26 deployed at the Pelican site in the Chandeleur Islands, Louisiana, from April 28, 2013, to July 16, 2013 .......................... 32

27. Water level and temperature time series from a Sea-Bird SBE 26+ deployed at the Tower site in the

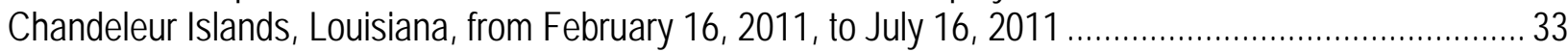

28. Wave statistics and time series of sensor depth relative to sea surface from a Sea-Bird SBE 26+ deployed at the Tower site in the Chandeleur Islands, Louisiana, from February 16, 2011, to July 16, 2011 ................. 34

29. Water level and temperature time series from a Sea-Bird SBE 26 deployed at the Tower site in the Chandeleur Islands, Louisiana, from July 11, 2012, to July 21, 2012

30. Wave statistics and time series of sensor depth relative to sea surface from a Sea-Bird SBE 26 deployed at the

Tower site in the Chandeleur Islands, Louisiana, from July 11, 2012, to July 21, 2012 36

31. Water level and temperature time series from a Sea-Bird SBE 26 deployed at the Tower site in the Chandeleur Islands, Louisiana, from July 21, 2012, to September 7, 2012 
32. Wave statistics and time series of sensor depth relative to sea surface from a Sea-Bird SBE 26 deployed at the

Tower site in the Chandeleur Islands, Louisiana, from July 21, 2012, to September 7, 2012. 38

33. Water level and temperature time series from a Sea-Bird SBE 26 deployed at the Tower site in the Chandeleur Islands, Louisiana, from September 7, 2012, to December 29, 2012. 39

34. Wave statistics and time series of sensor depth relative to sea surface from a Sea-Bird SBE 26 deployed at the

Tower site in the Chandeleur Islands, Louisiana, from September 7, 2012, to December 29, 2012........... 40

35. Water level and temperature time series from a Sea-Bird SBE 26 deployed at the Tower site in the Chandeleur Islands, Louisiana, from January 31, 2013, to April 28, 2013

36. Wave statistics and time series of sensor depth relative to sea surface from a Sea-Bird SBE 26 deployed at the Tower site in the Chandeleur Islands, Louisiana, from January 31, 2013, to April 28, 2013 42

37. Water level and temperature time series from a Sea-Bird SBE 26 deployed at the Tower site in the Chandeleur Islands, Louisiana, from April 28, 2013, to July 18, 2013............................................................. 43

38. Wave statistics and time series of sensor depth relative to sea surface from a Sea-Bird SBE 26 deployed at the Tower site in the Chandeleur Islands, Louisiana, from April 28, 2013, to July 18, 2013. 44

\section{Tables}

1. Mooring log sensor, location, and deployment information ............................................................... 45

2. Settings used in Sea-Bird Seasoft for Waves version 2.0 to process data from Sea-Bird Seagauges ......... 47

3. Instrumentation and data files for measurements of atmospheric pressure and temperature, water level, and waves, Chandeleur Islands, Louisiana, 2012 to 2013 


\section{Conversion Factors}

SI to Inch/Pound

\begin{tabular}{|c|c|c|}
\hline Multiply & By & To obtain \\
\hline \multicolumn{3}{|r|}{ Pressure } \\
\hline kilopascal (kPa) & 0.0099 & atmosphere, standard (atm) \\
\hline kilopascal (kPa) & 0.01 & bar \\
\hline kilopascal (kPa) & 0.296 & inch of mercury at $60^{\circ} \mathrm{F}$ (in $\mathrm{Hg}$ ) \\
\hline kilopascal (kPa) & 0.145 & pound-force per square inch (lbf/in²) \\
\hline kilopascal (kPa) & 20.89 & pound per square foot $\left(\mathrm{lb} / \mathrm{ft}^{2}\right)$ \\
\hline \multicolumn{3}{|r|}{ Length } \\
\hline centimeter $(\mathrm{cm})$ & 0.3937 & inch (in.) \\
\hline millimeter (mm) & 0.03937 & inch (in.) \\
\hline meter $(\mathrm{m})$ & 3.281 & foot $(\mathrm{ft})$ \\
\hline kilometer (km) & 0.6214 & mile (mi) \\
\hline kilometer (km) & 0.5400 & mile, nautical (nmi) \\
\hline meter (m) & 1.094 & yard (yd) \\
\hline
\end{tabular}

Temperature in degrees Celsius $\left({ }^{\circ} \mathrm{C}\right)$ may be converted to degrees Fahrenheit $\left({ }^{\circ} \mathrm{F}\right)$ as follows:

${ }^{\circ} \mathrm{F}=\left(1.8 \mathrm{x}^{\circ} \mathrm{C}\right)+32$

The SI unit for pressure is the pascal (Pa). $1 \mathrm{~Pa}=0.0001$ decibar (dbar) $=0.001$ kilopascal $(\mathrm{kPa})$.

Vertical coordinate information is referenced to North American Vertical Datum of 1988 (NAVD88).

Horizontal coordinate information is referenced to North American Datum of 1983 (NAD83).

Elevation, as used in this report refers, to distance above the vertical datum. 


\title{
Water-Level and Wave Measurements in the Chandeleur Islands, Louisiana, 2012 and 2013
}

\author{
By Patrick J. Dickhudt, Christopher R. Sherwood, and Nancy T. Dewitt
}

\begin{abstract}
This report documents measurements of atmospheric pressure, water levels, and waves made by the U.S. Geological Survey in the Chandeleur Islands, Louisiana, during 2012 and 2013 as part of the Barrier Island Evolution Research project. Simple, inexpensive pressure sensors mounted in shallow wells were buried in the beach and left for one hurricane season and one winter-storm season. Gauges with rapid-sampling pressure sensors that provided nondirectional wave data and water-level data were mounted on rugged mounts on the Chandeleur Sound side and at the base of a tower at the northern end of the island chain. Additionally, an atmospheric pressure sensor was mounted on the tower to provide a local atmospheric pressure measurement for correcting the submerged pressure records.
\end{abstract}

\section{Introduction}

The U.S. Geological Survey (USGS) measured atmospheric pressure, water levels, and waves in the barrier island system of the Chandeleur Islands, Louisiana, during 2012 and 2013 as part of the Barrier Island Evolution Research (BIER) project. Barrier islands are dynamic systems that can experience substantial morphological change (erosion and deposition) during storms. Water levels around barrier islands are influenced by winds, waves, and atmospheric pressure during the passage of storms, and the morphological effect of storms depends, in part, on the magnitude of inundation and water-level gradients across the island. Direct water-level measurements on barrier islands during storms are somewhat uncommon because equipment is often lost, buried, or destroyed during these high-energy events.

This report describes the instrumentation, field methods, and data processing techniques used to measure water levels and waves with relatively inexpensive pressure sensors in a rapidly evolving barrier island system (fig. 1). These water-level and wave measurements can be used to validate numerical models and to help interpret the morphological response of the islands to storms.

\section{Instrumentation}

\section{Well Installation}

Pressure sensors buried in the beach were encased in 4.8-centimeter (cm; outside diameter) schedule 80 polyvinyl chloride (PVC) slotted well casings. The well casings were about 1.5 meters (m) long and were screened with 0.15 -millimeter-wide slots along most of their length. A PVC well point with a 1.25-cm-diameter hole drilled through its center (to allow a water jet to exit) was screwed to the lower end of each well. Wells were installed by first digging a shallow hole (30 to $50 \mathrm{~cm}$ deep) and then 
using a battery-powered bilge pump to jet the well into the sand until the top of the well was below the level of the beach (fig. 2). A pressure sensor was hung from a threaded rod attached to a PVC cap that screwed into the top of the well after jetting. The distance from the well cap to the pressure sensor is provided in table 1 and approximates the pressure-sensor depth below the sediment surface.

The elevation of the well cap was established using post-processed static Global Positioning System (GPS) data. A GPS base station was placed on a USGS-installed benchmark referred to as TMRK on the Chandeleur Island chain, and a rover unit was used to survey the wells. The error between the base and the rover increased exponentially with distance from the base station (Waypoint Consulting Inc., 2005) as reflected by an increase in the root mean squared (RMS) error of the differentially corrected navigation data. All wells were within 5 kilometers $(\mathrm{km})$ of the base station.

The GPS base station and the rover were duplicate systems with Ashtech Z-Xtreme GPS receivers, internal data recorders, Thales choke-ring antennae, and tripods (fig. 3A). After the wells were installed, the GPS rover was positioned and referenced to a dimple on the well cap (fig. 3B). Both receivers recorded the 12-channel full-carrier-phase positioning signals (L1/L2) from the satellites and recorded their positions concurrently at 1 -second intervals for at least 30 minutes (min). This 30-min GPS static occupation session was repeated when the wells were recovered months later.

All GPS static sessions were processed using NovAtel GrafNet version 8.3 software, accounting for antenna height, antenna model, and GPS session type (rover or base). The processed position heights were referenced to the top of the well cap and converted to NAD83 (CORS96) using the National Geodetic Survey (NGS) Horizontal Time-Dependent Positioning utility. These processed heights were then processed through the NGS GEOID96 model to obtain a geoid height. The elevation of the pressure sensor was then determined by subtracting the distance from the well cap to the pressure sensor (table 1) from the cap elevation.

The uncertainty of the elevation of the water-level sensor was estimated by using the square root of the sum of the squared individual error terms. The individual error terms included difference in surveyed well cap heights as measured upon deployment and recovery, the estimated error in the length of the threaded rods the sensors were suspended from, and the standard deviation of the GPS elevation measurements for a particular well. The estimated uncertainty in the elevations of the water-level sensors ranged from 0.002 to $0.016 \mathrm{~m}$ (table 1 ).

\section{RBR DR1060 Pressure Logger}

The RBR DR1060 (fig. 4) is a small, submersible pressure logger capable of recording more than 2 million samples at frequencies up to 1 hertz $(\mathrm{Hz})$. These pressure loggers were temperature compensated and had pressure sensors with a depth rating of $10 \mathrm{~m}$. The manufacturer-specified accuracy was \pm 0.05 percent of full scale (about 0.005 -m water depth) and resolution was 0.001 percent of full scale (about 0.0001-m water depth). Each RBR DR1060 was mounted on a rigid metal rod connected to the cap of a buried well jetted into the beach (described in "Well Installation"). The RBR DR1060s recorded pressure every 5 seconds. At this sample rate, the RBR DR1060s could sample for about 5 months before running out of memory.

\section{Onset Hobo U20 Water-level Logger}

The Onset Hobo U20 water-level logger (fig. 5) is a small, submersible pressure logger capable of recording about 22,000 pressure and temperature samples at rates up to $1 \mathrm{~Hz}$. Two types of Onset Hobo U20s were deployed: an atmospheric pressure sensor with a range of 0 to 15 decibars and a submerged sensor with a range of 0 to 21 decibars (about $0-9-m$ water depth). The atmospheric sensor 
has an accuracy of \pm 0.3 percent of full scale and resolution of 0.01 percent of full scale. The submerged sensor has a water-level accuracy of 0.05 percent of full scale (about $0.005-\mathrm{m}$ water depth) and waterlevel resolution of 0.002-m water depth.

The U20-001-04 sensor used as an atmospheric sensor was mounted in a small white PVC tube with vents and attached with hose clamps to the radio tower at the northern end of the Chandeleurs (figs. 1 and 6). The sensor was mounted about $4 \mathrm{~m}$ above the sea surface. The submerged Onset Hobo U20s were mounted on rigid metal rods connected to the caps of buried wells jetted into the beach (described in "Well Installation"). Each Onset Hobo U20 collected a pressure measurement every 600 seconds for the duration of the deployment. At this sample rate, the Onset Hobo U20s could sample for about 5 months before running out of memory.

\section{Sea-Bird Seagauge Wave and Tide Recorder}

The Sea-Bird Seagauge SBE 26 (fig. 7) is a submersible pressure logger capable of making periodic and burst pressure measurements to determine water level and waves. The Seagauges were equipped with Digiquartz temperature-compensated pressure sensors. Seagauge serial number 1099, which was deployed at the tower from February to July 2011, had a pressure sensor rated at 0 to 138 decibars (about $125 \mathrm{~m}$ of water depth) with an accuracy of \pm 0.01 percent of full scale (about $0.013-\mathrm{m}$ water depth) and a resolution of about 0.0009-m water depth. The other three Seagauges had pressure sensors rated at 0 to 31 decibars (about 20 -m water depth) with accuracies of \pm 0.01 percent (about 0.003-m water depth) and resolutions of 0.0002-m water depth.

The Seagauges at the Pelican site were bolted to a rigid mount on a pole that was jetted into the seabed and left for the duration of the project. The Seagauges at the Tower site were bolted to a rigid mount attached to a leg of the tower and were deployed by SCUBA divers.

Each Seagauge recorded a tide measurement (single pressure reading) every 20 minutes and recorded a 2,048-sample burst at a rate of $4 \mathrm{~Hz}$ every 240 minutes. Seagauge wave data were processed using Sea-Bird Seasoft for Waves version 2.0 software with the settings specified in table 2.

\section{Site Description}

\section{Chandeleur Islands, Louisiana}

The Chandeleur Islands (fig. 1) are a chain of uninhabited, low-lying islands bordered to the west by Chandeleur Sound and to the east by the Gulf of Mexico. The islands are sandy and partially vegetated, and they sit atop the abandoned St. Bernard lobe of the Mississippi delta. Table 1 provides the exact locations of each study site in the Chandeleur Islands.

\section{Pelican SBE 26}

The Pelican site was in a small bay on the Chandeleur Sound side of the islands near the Pelican fishing camp. A pole was jetted into the sediment in about $1.5 \mathrm{~m}$ of water, and a Sea-Bird SBE 26 pressure sensor was bolted to the pole to measure water levels and wave heights on the Chandeleur Sound side of the islands. The SBE 26 pressure sensor was $0.85 \mathrm{~m}$ above the seafloor. Sensors were deployed at the Pelican site almost continuously from February 2012 to July 2013 (table 1). 


\section{Tower SBE 26 and Atmospheric Pressure Sensors 946, 947, 951}

The Tower site is a radio tower on the northern end of the Chandeleur Island chain in about $5 \mathrm{~m}$ of water (fig. 1c). A Sea-Bird SBE 26 pressure sensor was bolted to a fixed mount near the base of the tower to measure water levels and wave heights on the exposed Gulf of Mexico side of the islands. The SBE 26 pressure sensor was $0.85 \mathrm{~m}$ above the seafloor. Sensors were deployed at the Tower site from February 2011 to July 2011 and almost continuously from July 2012 to July 2013 (table 1).

Sites 946, 947, and 951 represent sequential deployments on the Tower site on the northern end of the Chandeleur Island chain. An Onset Hobo U20 atmospheric pressure sensor was mounted in a PVC tube hose-clamped to the tower about $4 \mathrm{~m}$ above the sea surface. Sites 946, 947, and 951 are in the same location; a new site number was given each time the sensor was redeployed. The sensor at 946 was deployed from July 11, 2012, to September 7, 2012. The sensor at 947 was deployed from September 7, 2012, to January 31, 2013. The sensor at 951 was deployed from February 2, 2013, to July 18, 2013.

\section{Buried Well Sites 942, 943, 944, and 945}

Sites 942, 943, 944, and 945 were beach well sites occupied during the 2012 hurricane season. They were deployed on July 10, 2012, and recovered on September 7, 2012, after Hurricane Isaac.

\section{Site 942}

Site 942 was on the western (Chandeleur Sound) side of the island at the western end of an intermittently active overwash channel. An RBR DR1060 pressure sensor was mounted in a well buried in the beach.

\section{Site 943}

Site 943 was on the eastern (Gulf of Mexico) side of the island in the same overwash channel as 942. An RBR DR1060 pressure sensor was mounted in a well buried in the beach.

\section{Site 944}

Site 944 was on the western (Chandeleur Sound) side of the island at the western end of an intermittently active overwash channel. An Onset Hobo U20 pressure sensor was mounted in a well buried in the beach. The sensor at site 944 was lost during Hurricane Isaac when this portion of the island underwent substantial erosion.

\section{Site 945}

Site 945 was on the eastern (Gulf of Mexico) side of the island in the same overwash channel as 944. An Onset Hobo U20 pressure sensor was mounted in a well buried in the beach. The sensor at site 945 was lost during Hurricane Isaac when this portion of the island underwent substantial erosion.

\section{Buried Well Sites 948, 949, 950}

Sites 948, 949, 950 were beach well sites, occupied during the 2013 hurricane season, that transected an overwash channel (site 942 from 2012). They were all deployed on February 1, 2013. The 
sensors at 948 and 949 were recovered on July 16, 2013. The sensor at site 950 was recovered on March 15, 2013, when it was discovered by a fisherman.

\section{8}

Site 948 was very near site 942 on the Chandeleur Sound side of the island at the western end of the intermittently active overwash channel. An RBR DR1060 pressure sensor was mounted in a well buried in the beach.

\section{9}

Site 949 was directly between sites 948 and 950 at the approximate crest of the island. An Onset Hobo U20 pressure sensor was mounted in a well buried in the beach.

\section{0}

Site 950 was very near site 943 on the Gulf of Mexico side of the island at the eastern end of the overwash channel. An RBR DR1060 pressure sensor was mounted in a well buried in the beach.

\section{Results}

Atmospheric pressure data were collected continuously at the Tower site from July 2012 to July 2013 (table 1). The data appear to be of good quality but differ at times from data collected by the nearest land-based atmospheric pressure sensors. Specifically, the sensors at the Tower site show larger variations in pressure than the sensors at National Oceanic and Atmospheric Administration (NOAA) gauge PTBM6 at Petit Bois Island, Mississippi, approximately $40 \mathrm{~km}$ northeast of the Tower site (fig. 8). These pressure excursions may be real (for example, due to short-term pressure fluctuations caused by frontal passages) or they may be artifacts of sensor exposure to sun and wind. Time series plots of atmospheric pressure and temperature are shown in figures 9 through 11.

Pressure sensors encased in wells buried in the beach were deployed from July 2012 to September 2012 and from February 2013 to July 2013 (table 1). All data from the wells were of very high quality with no evidence of error due to fouling or attenuation due to burial. Two sensors (at 944 and 945) were lost during Hurricane Isaac in August of 2012 when substantial parts of the islands were lost to erosion. The sensor deployed at site 950 was recovered early (March 2013) when a fisherman discovered it and mistook it for one of the sensors lost during Hurricane Isaac.

Water levels were derived from the well pressure sensors by subtracting atmospheric pressure linearly interpolated (in time) from measurements taken every 6 minutes at NOAA gauge PTBM6. The corrected pressure data were converted from decibars to water depth using an assumed seawater density of 1022.9 kilograms per cubic meter (calculated from salinity of 34 practical salinity units and temperature of 24 degrees Celsius, a typical salinity and approximately the mean temperature) and adjusted to a common datum (North American Vertical Datum of 1988 [NAVD88]) using the surveyed cap elevation and the measured distance from the cap to the pressure sensor (table 1). Time series plots of water-level data from the buried wells are shown in figures 12 through 16. In the water-level plots, the reported water level is NAVD88 orthometric height, referenced to the NGS GEOID96 datum.

Water-level and wave data were collected at the Tower site for 5 months in 2011, almost continuously at the Pelican site from February 2012 to July 2013, and almost continuously at the Tower site from July 2012 to July 2013 (table 1). The data were of high quality with no evidence of error or 
drift due to fouling. Water-level information was derived from the SBE 26 sensors with Sea-Bird Seasoft software by subtracting atmospheric pressure linearly interpolated (in time) from measurements taken every 6 minutes at NOAA gauge PTBM6. The corrected pressure data were converted from decibars to water depth using the algorithms provided in Unesco (1983) and were adjusted to a common datum (NAVD88) using the surveyed sensor elevation.

Wave statistics were calculated using Sea-Bird Seasoft for Waves version 2.0 software with the settings provided in table 2 . Wave processing was sensitive to the user-selected high-frequency cutoff. The small waves at the Pelican and Tower sites and the amplification of high-frequency noise when the wave spectra were corrected for depth attenuation resulted in overestimates of wave height and underestimates of wave period. Setting the minimum period (high-frequency cutoff) to 1.5 seconds for data from the Pelican site and 4 seconds for data from the Tower site improved the quality of the calculated wave statistics. Additionally, the data from the Pelican site were processed using a maximum period of 15 seconds. This site had extremely small waves for most of the study period, and enforcing this maximum period removed waves that were small $(<0.03 \mathrm{~m})$ with long periods (for example, 100 seconds). Time series plots of water level and wave data from the Sea-Bird SBE 26 mounted at the Pelican site are shown in figures 17 through 26. Time series plots of water level and wave data from the Sea-Bird SBE 26 mounted at the Tower site are shown in figures 27 through 38.

Data from all instruments were converted to standard format for USGS time series (Montgomery and others, 2009) in network common data format (netCDF) files. NetCDF files store data and associated metadata in a format that is compact and machine-independent. Documentation of the USGS Oceanographic Time-Series Measurement Database can be found in Montgomery and others (2009). Details of instrumentation used for measurement of atmospheric pressure, water levels, and waves are provided in tables 3,4 , and 5 .

\section{References Cited}

Montgomery, E.T., Martini, M.A., Lightsom, F.L., and Butman, Bradford, 2009, Documentation of the U.S. Geological Survey oceanographic time series measurement database (February 2009 revision): U.S. Geological Survey Open-File Report 2007-1194, http://pubs.usgs.gov/of/2007/1194/.

Unesco, 1983, Algorithms for computation of fundamental properties of seawater: Unesco Technical Papers in Marine Science 44, 53 p.

Waypoint Consulting Inc., 2005, Static baseline accuracies as a function of baseline length, observation time and the effect of using the precise ephemeris: Waypoint Consulting Incorporated, 12 p., accessed September 2, 2014, at http://www.novatel.com/assets/Documents/Waypoint/Reports/Static_Accuracies.pdf. 


\section{Figures}
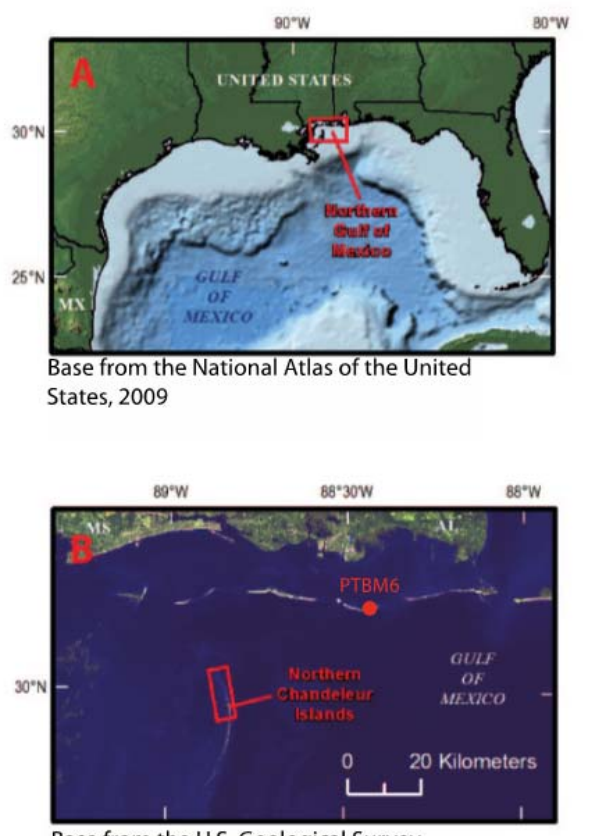

Base from the U.S. Geological Survey, Landsat 8 satellite imagery, 2013

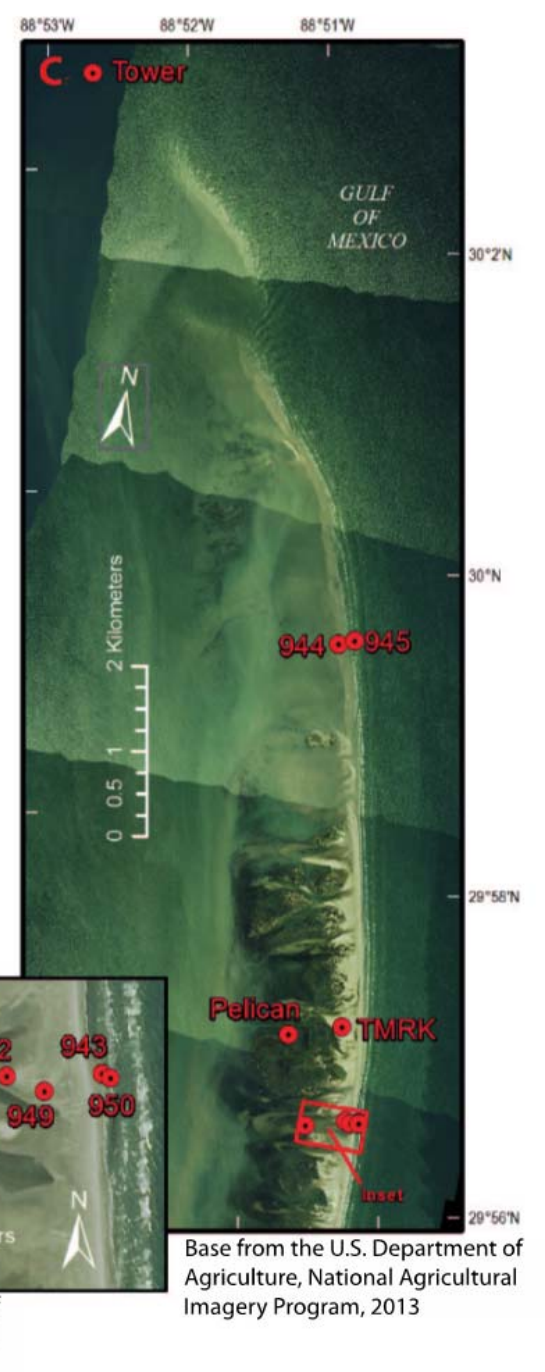

Figure 1. Maps showing, at increasingly greater scales, the study area and locations of sensors used to monitor atmospheric pressure, water level, and waves in the Chandeleur Islands, Louisiana, during 2012 and 2013. A, Gulf of Mexico; $B$, northern Gulf of Mexico; $C$, northern Chandeleur Islands and sensor locations; and $D$, locations of recovered buried well sensors within the area designated by the inset in $C$. Red dots indicate sensor locations. 


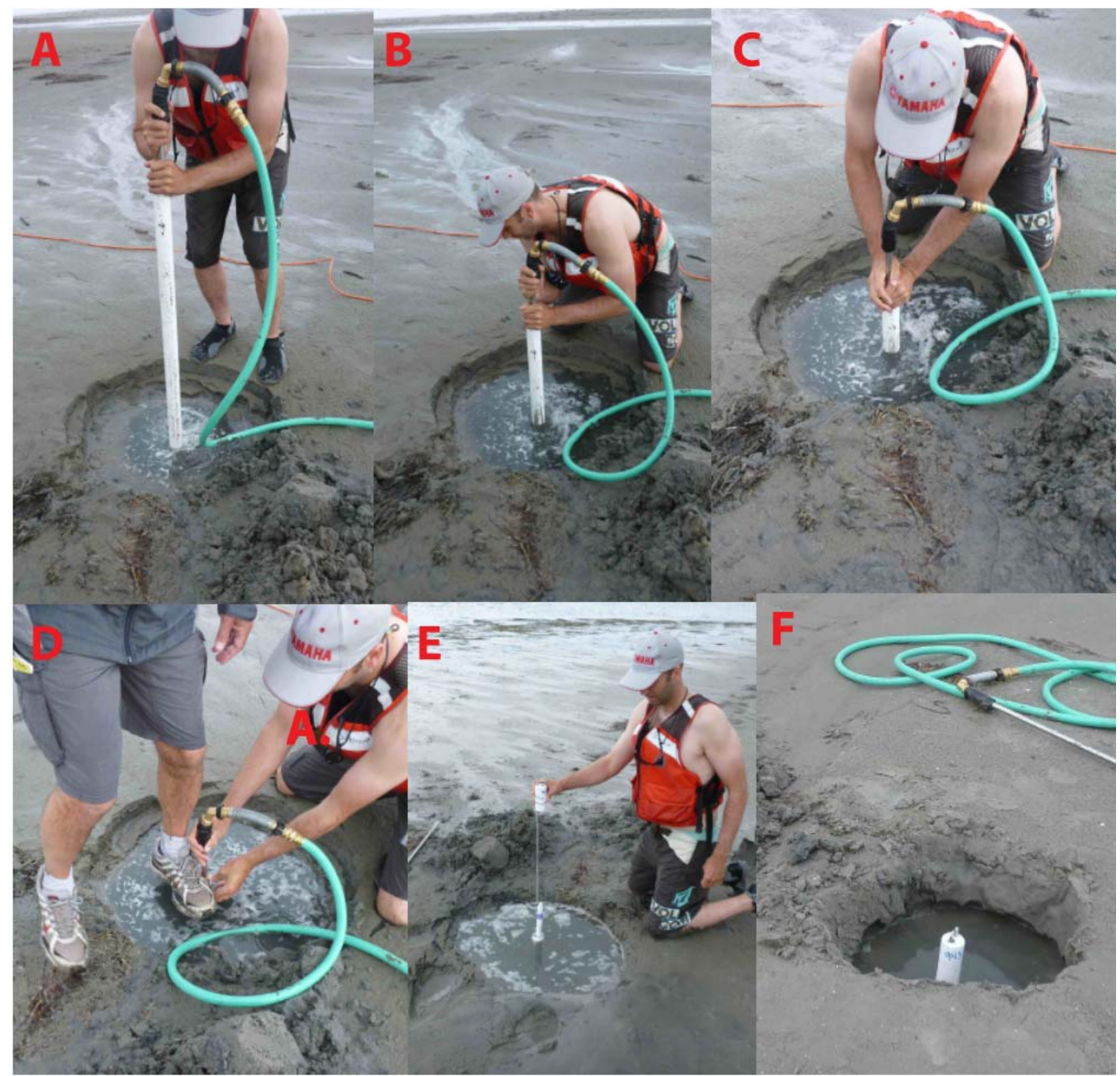

Figure 2. Photographs illustrating the procedure for installing a buried well. $A C$, the well casing being jetted into the sand; $D$, the well casing at the end of jetting; $E$, the pressure sensor being inserted into the casing; $F$, the completed installation with the pressure sensor inserted and the cap screwed into the well casing. 


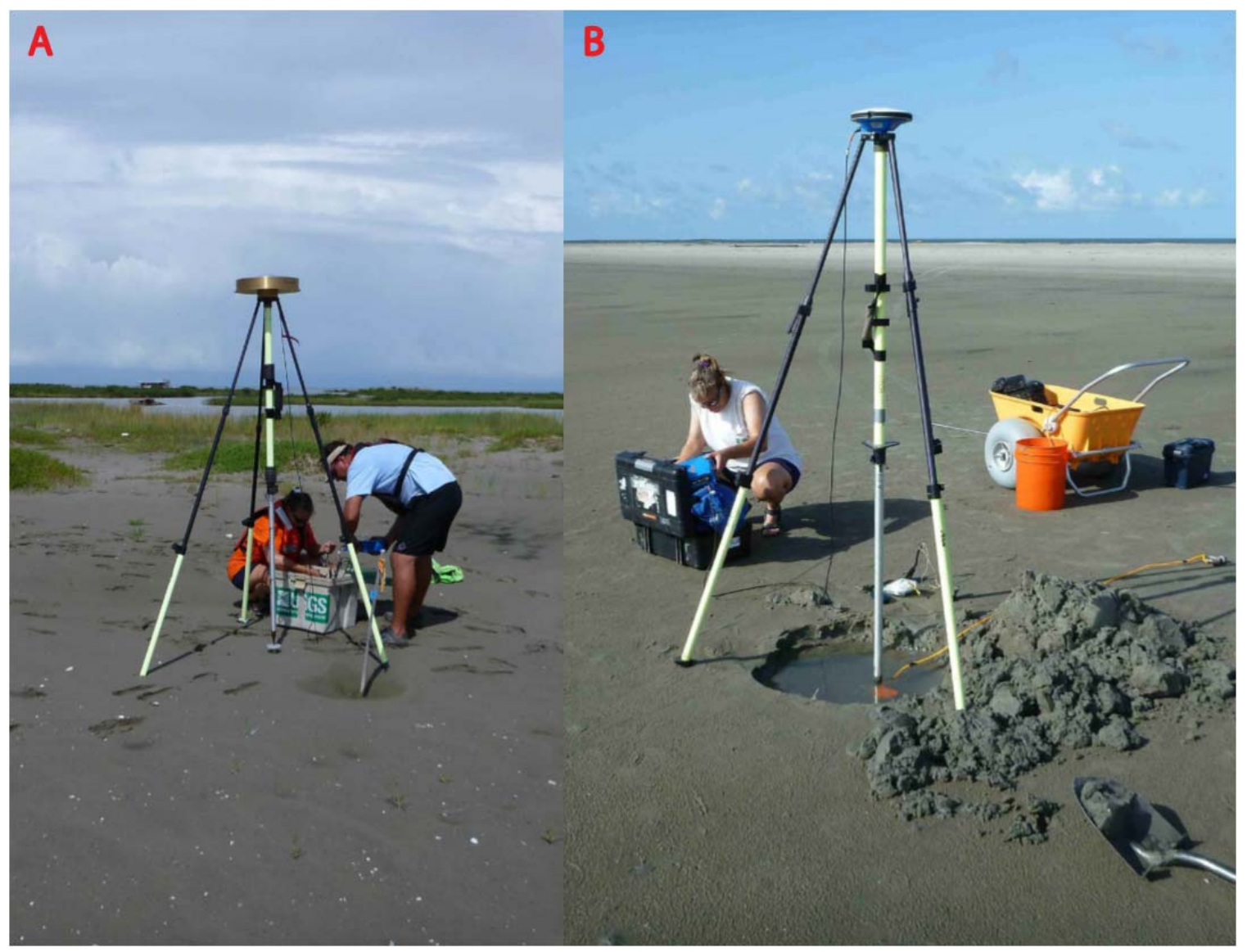

Figure 3. Photographs of $A$, USGS scientists Nancy Dewitt and Kyle Kelso installing the Global Positioning System (GPS) base station and B, Nancy Dewitt surveying a well with the GPS rover (after installation and prior to burial) to provide precise information about the location and elevation of the buried pressure sensor. 


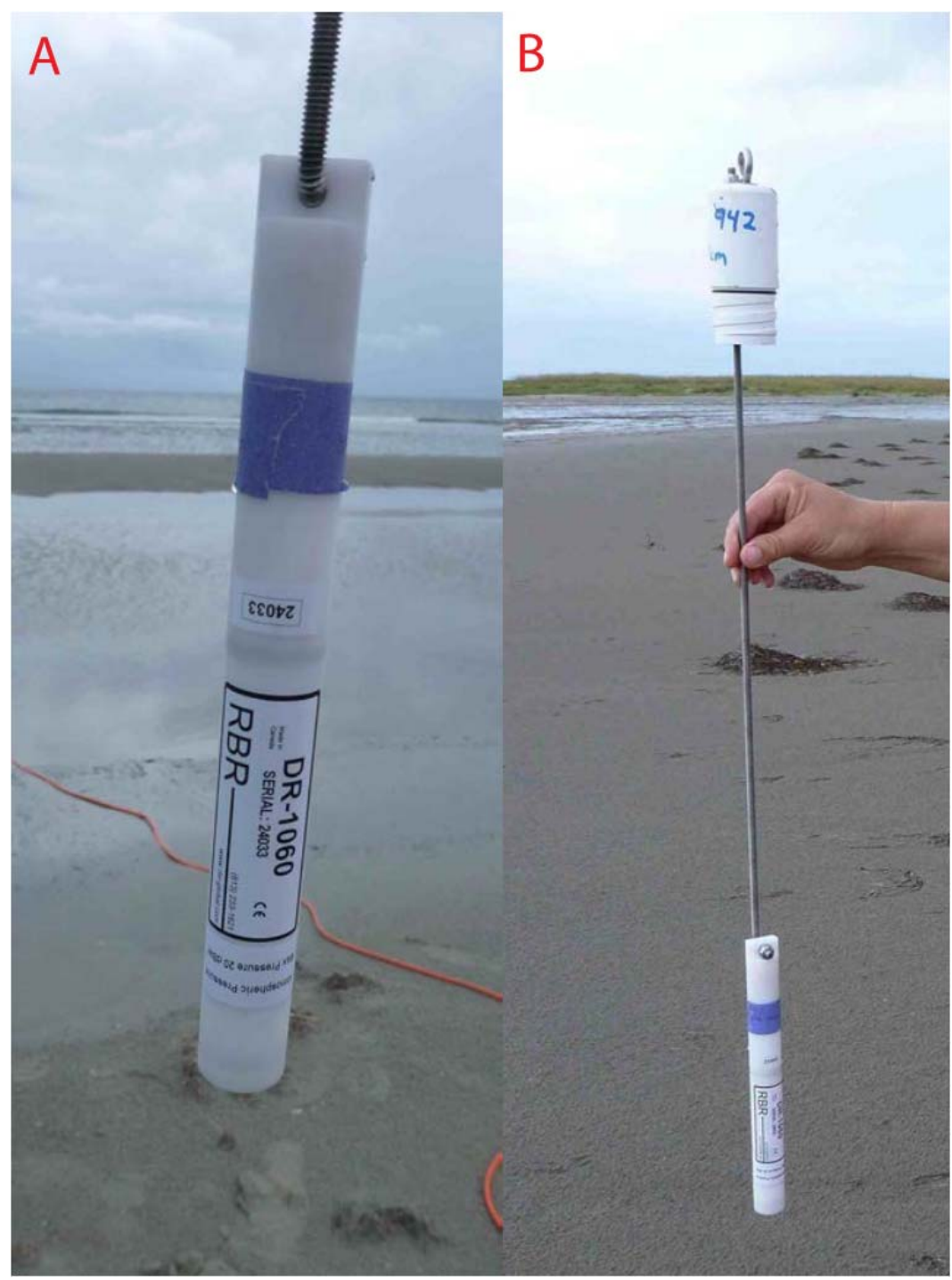

Figure 4. Photographs of an RBR DR1060 pressure logger. $A$, Close-up of RBR DR1060 pressure logger. $B$, RBR DR1060 pressure logger connected to well cap by threaded stainless-steel rod. Pressure sensor is inserted into well casing, and cap is screwed onto top of well as shown in figure $3 E$. 


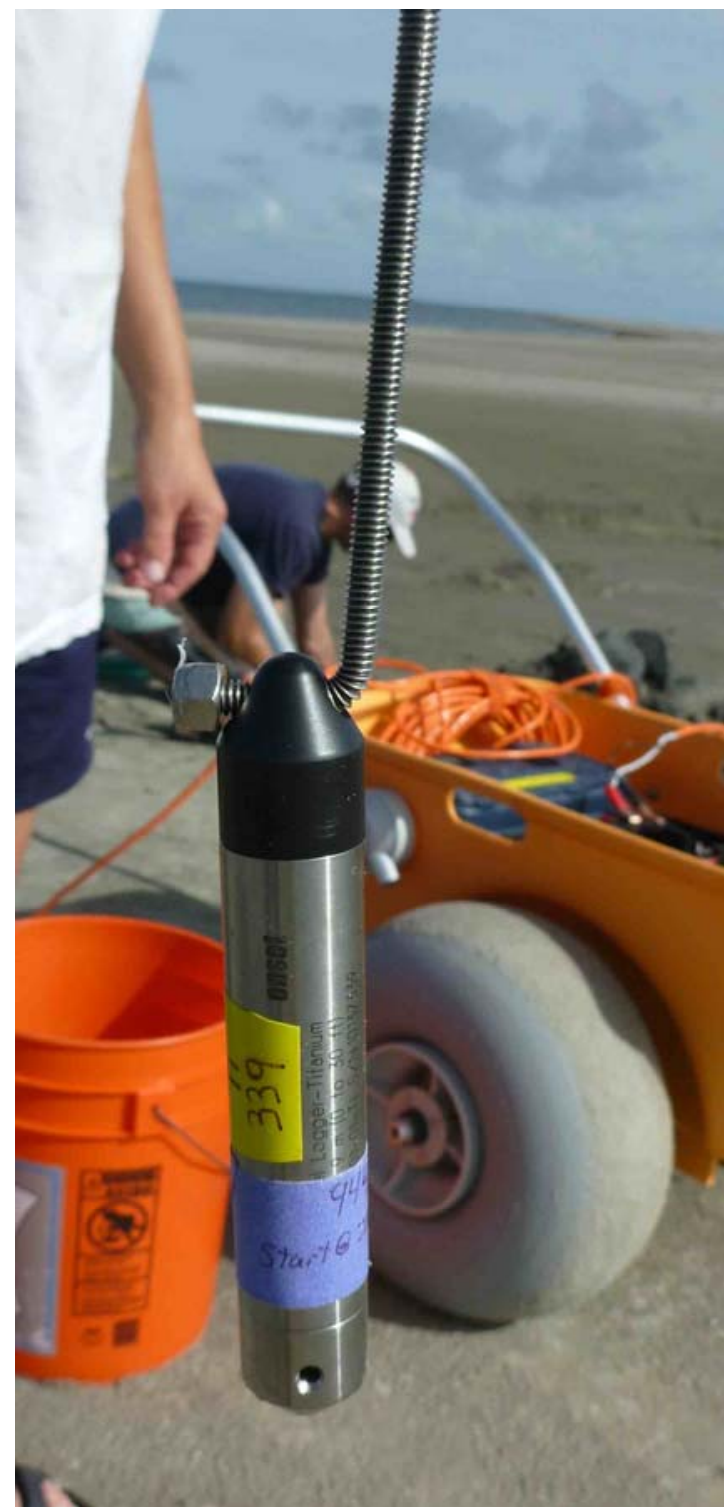

Figure 5. Photograph of an Onset Hobo U20 pressure logger and threaded stainless-steel rod. 


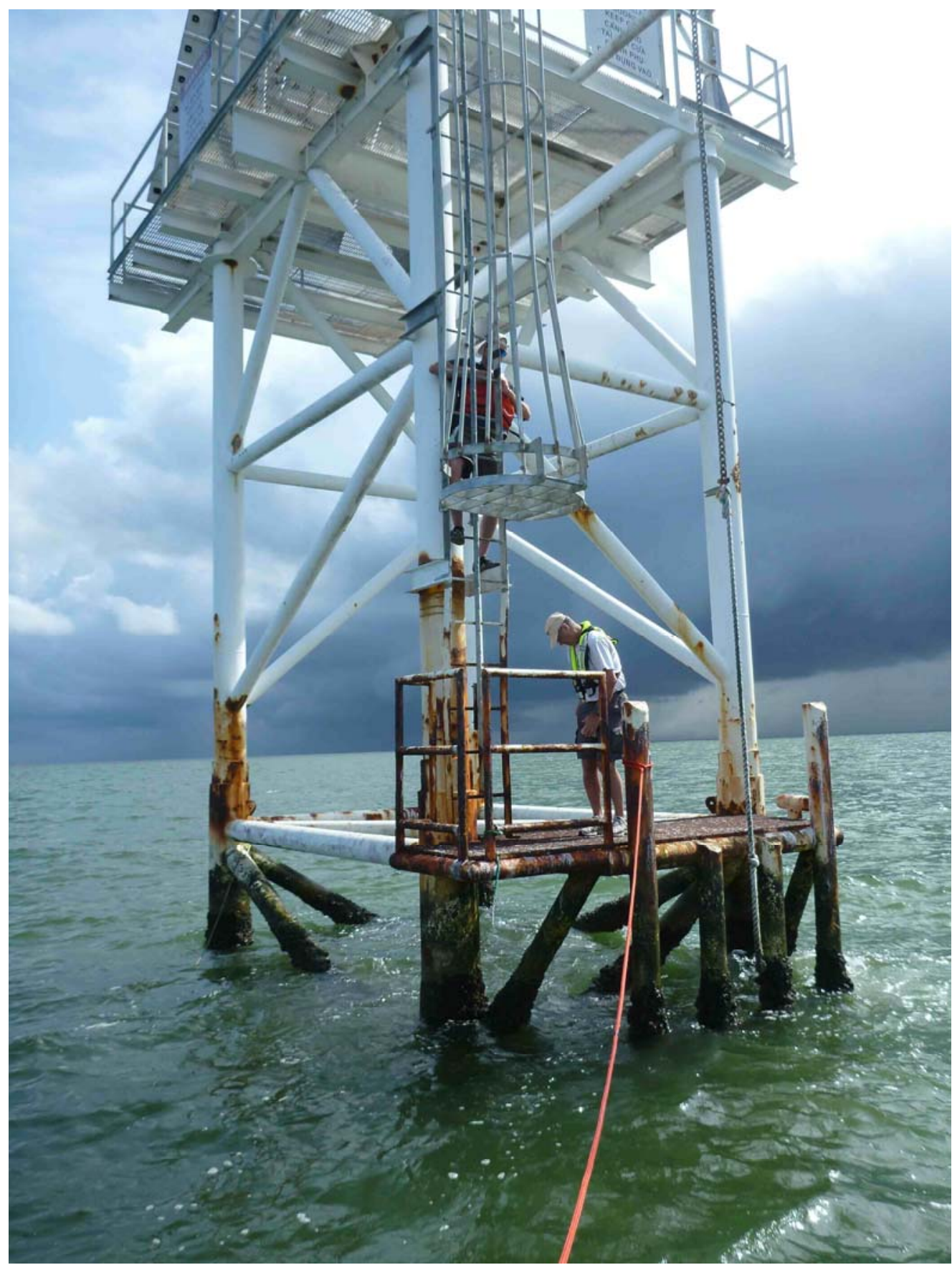

Figure 6. Photograph of Onset Hobo U20 atmospheric pressure sensor being mounted on tower by Patrick Dickhudt and Chris Sherwood. 




Figure 7. Photograph of Sea-Bird SBE 26 wave and water-level sensor after being recovered from tower by USGS scientists B.J. Reynolds (pictured) and Kyle Kelso. 


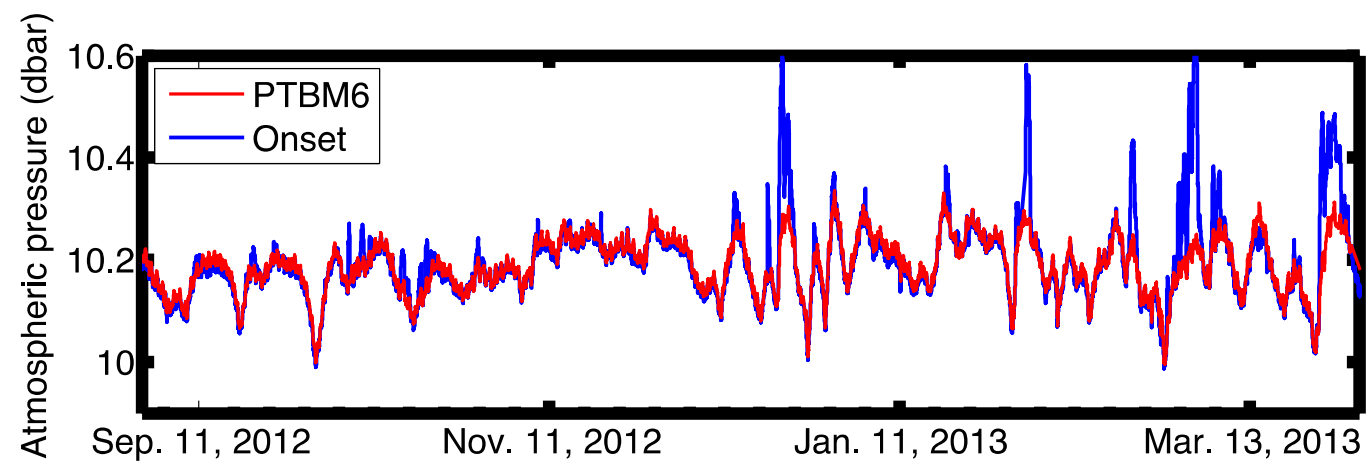

Figure 8. Portion of atmospheric pressure time series from National Oceanic and Atmospheric Administration (National Data Buoy Center) station PTBM6 and Onset Hobo U20 pressure sensors on Tower site, Chandeleur Islands, Louisiana, 2012 to 2013. dbar, decibars. 

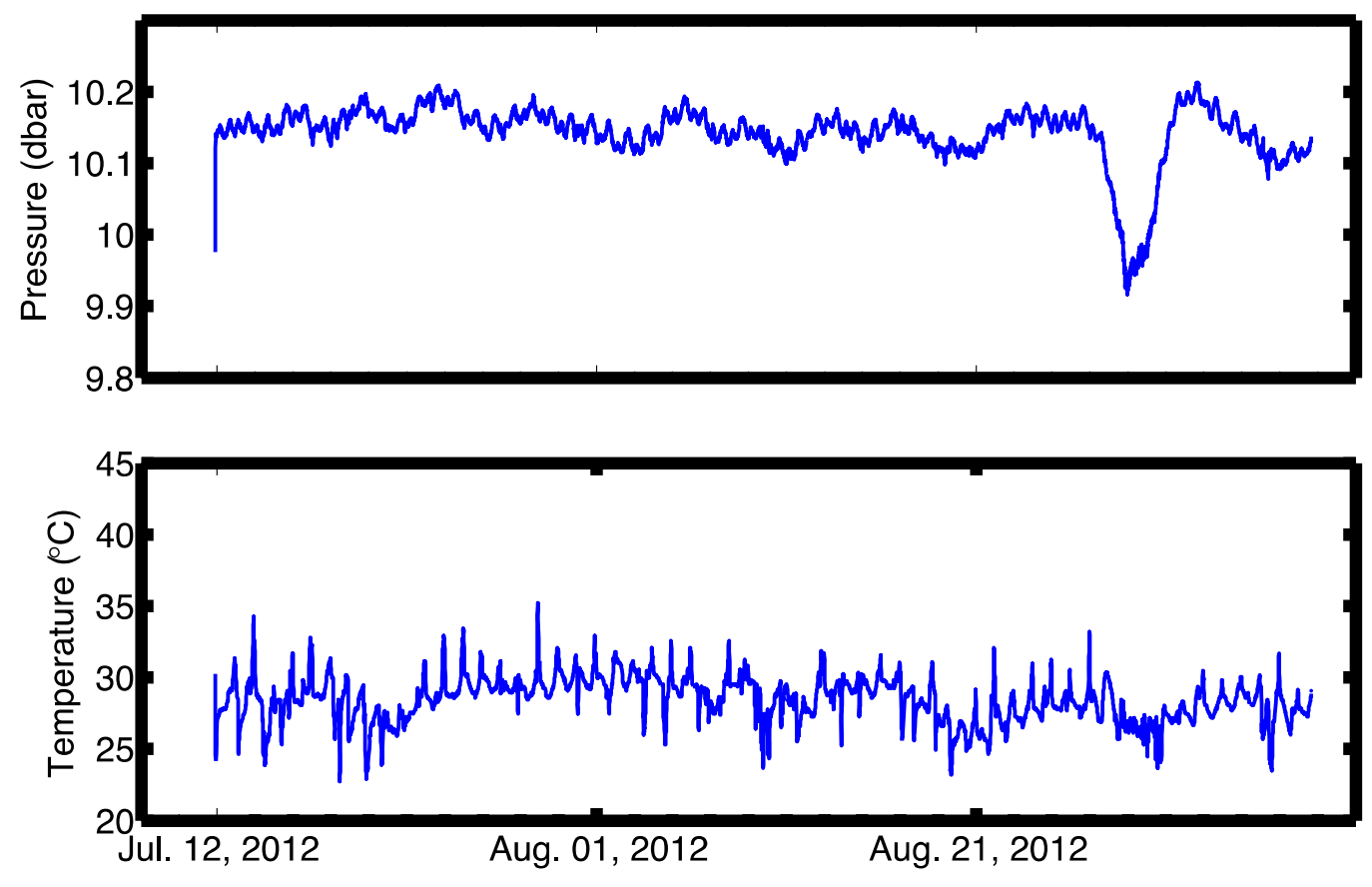

Figure 9. Atmospheric pressure and temperature time series from an Onset Hobo U20 atmospheric pressure sensor mounted on the tower at Site 946, Chandeleur Islands, Louisiana, from July 11 through September 7, 2012. The passage of Hurricane Isaac is evident by the sharp change in atmospheric pressure on August 29 and 30. dbar, decibars; ${ }^{\circ} \mathrm{C}$, degrees Celsius. 

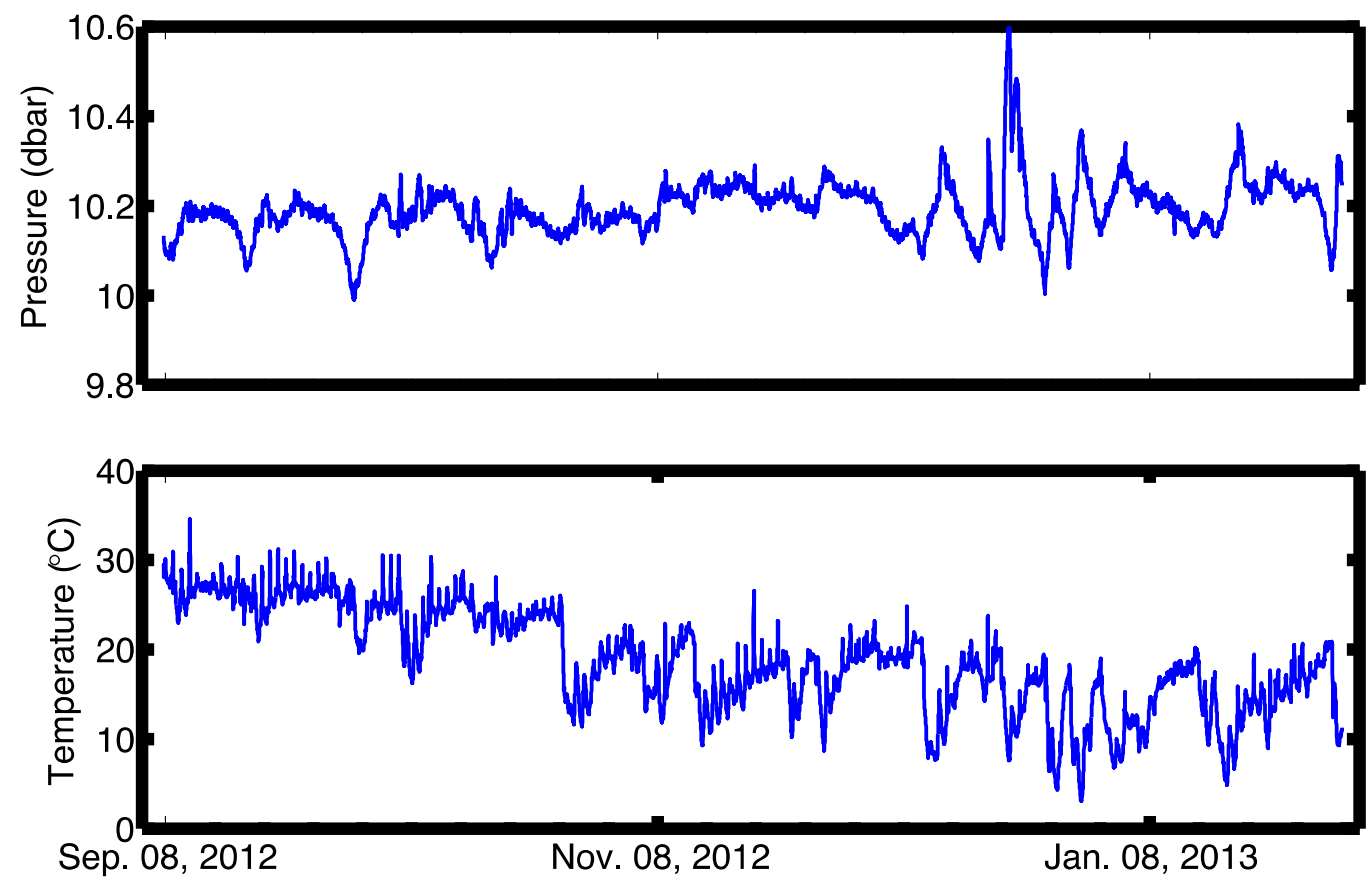

Figure 10. Atmospheric pressure and temperature time series from an Onset Hobo U20 atmospheric pressure sensor mounted on the tower at Site 947, Chandeleur Islands, Louisiana, from September 7, 2012 to January 31, 2013. dbar, decibars; ${ }^{\circ} \mathrm{C}$, degrees Celsius. 

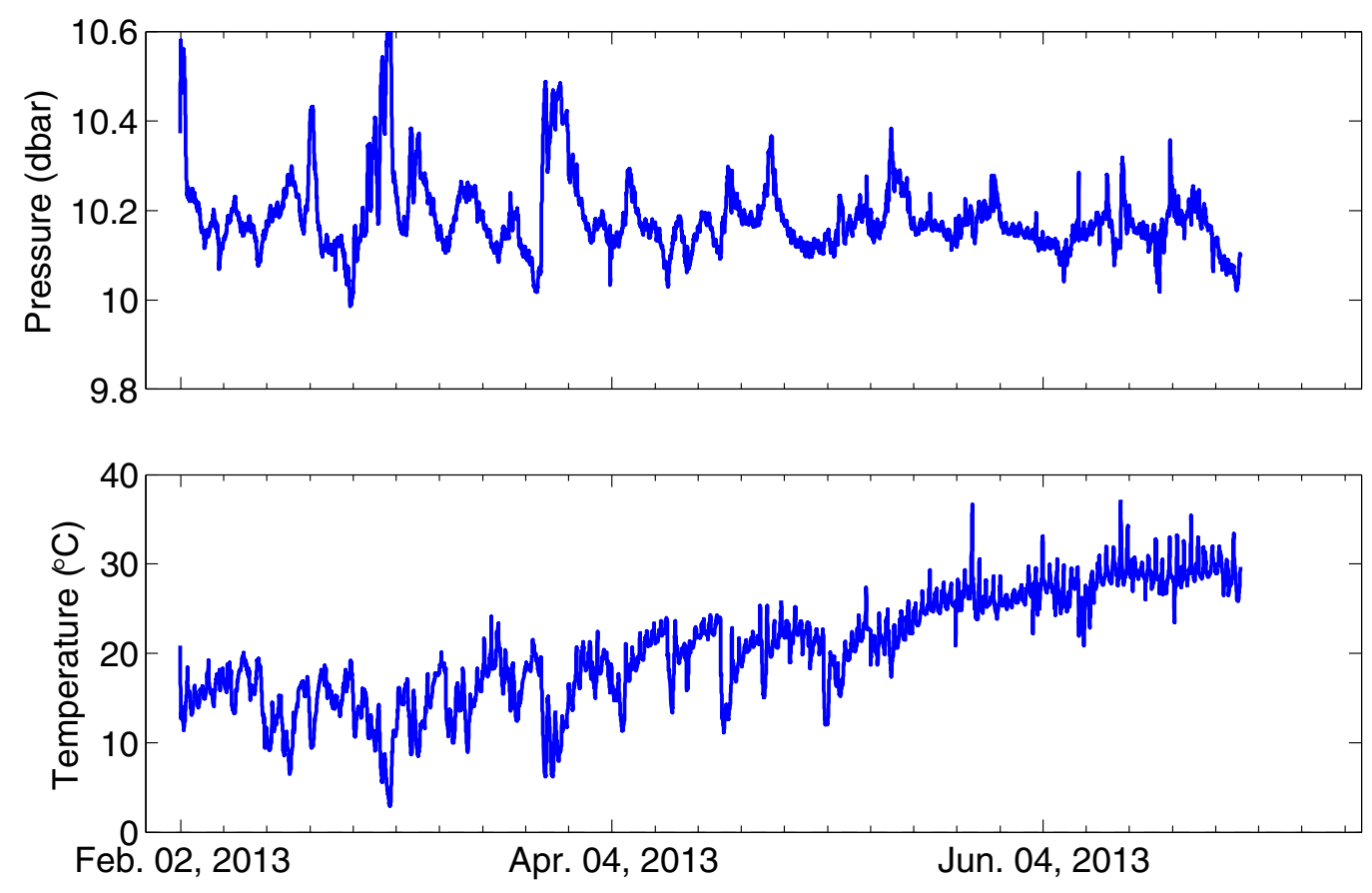

Figure 11. Atmospheric pressure and temperature time series from an Onset Hobo U2O atmospheric pressure sensor mounted on the tower at Site 951, Chandeleur Islands, Louisiana, from February 1 through July 18, 2013. dbar, decibars; ${ }^{\circ} \mathrm{C}$, degrees Celsius. 


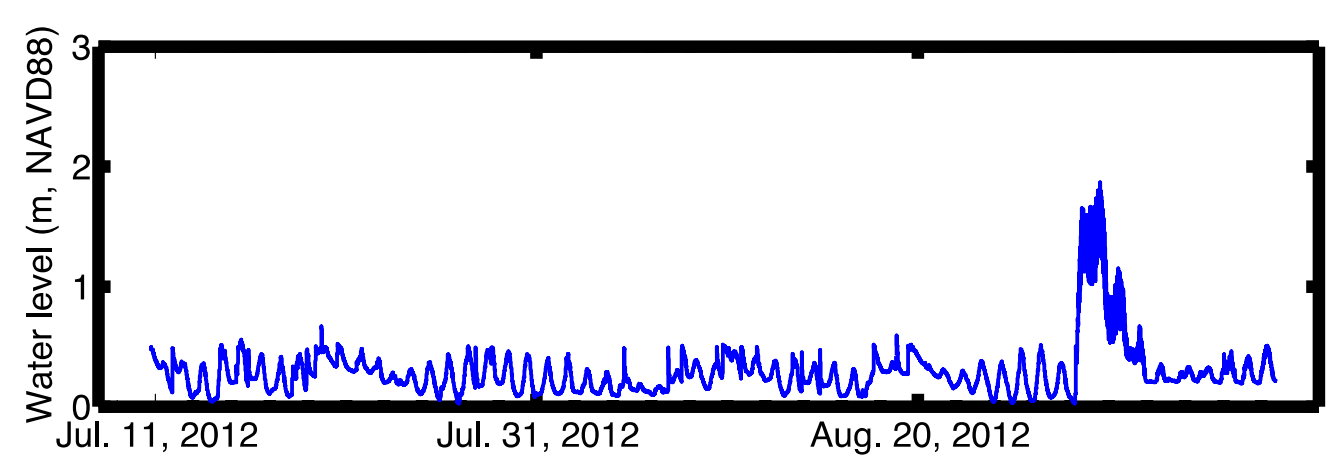

Figure 12. Water level time series from an RBR DR1060 pressure logger mounted in a buried well at Site 942, Chandeleur Islands, Louisiana, from July 10 through September 7, 2012. The passage of Hurricane Isaac is evident by the increase in water level on August 29 and 30. m, meters; NAVD88, North American Vertical Datum of 1988. 


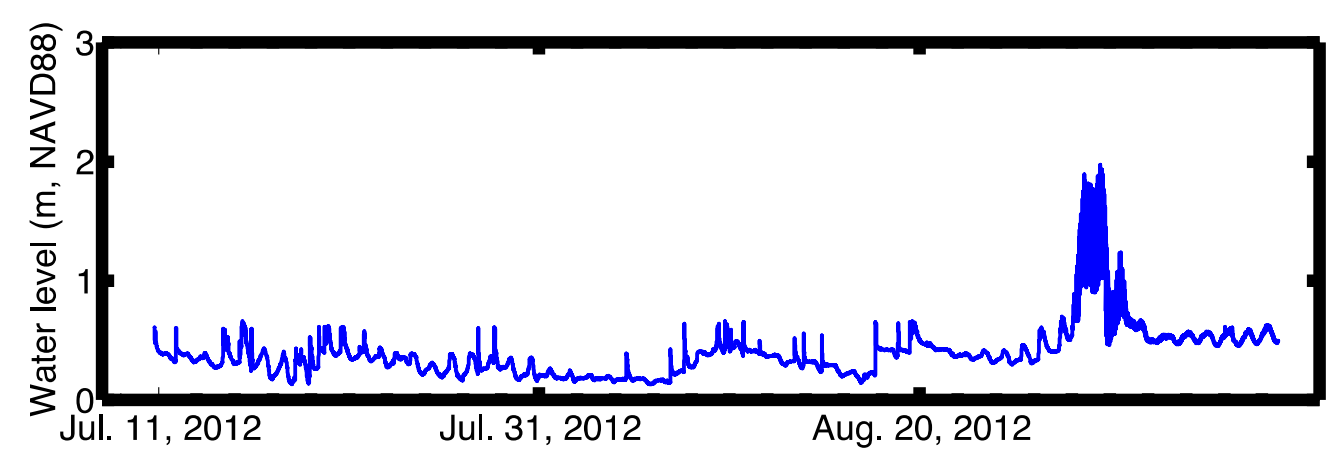

Figure 13. Water level time series from an RBR DR1060 pressure logger mounted in a buried well at Site 943 Chandeleur Islands, Louisiana, from July 10 through September 7, 2012. The passage of Hurricane Isaac is evident by the increase in water level on August 29 and 30. m, meters; NAVD88, North American Vertical Datum of 1988. 


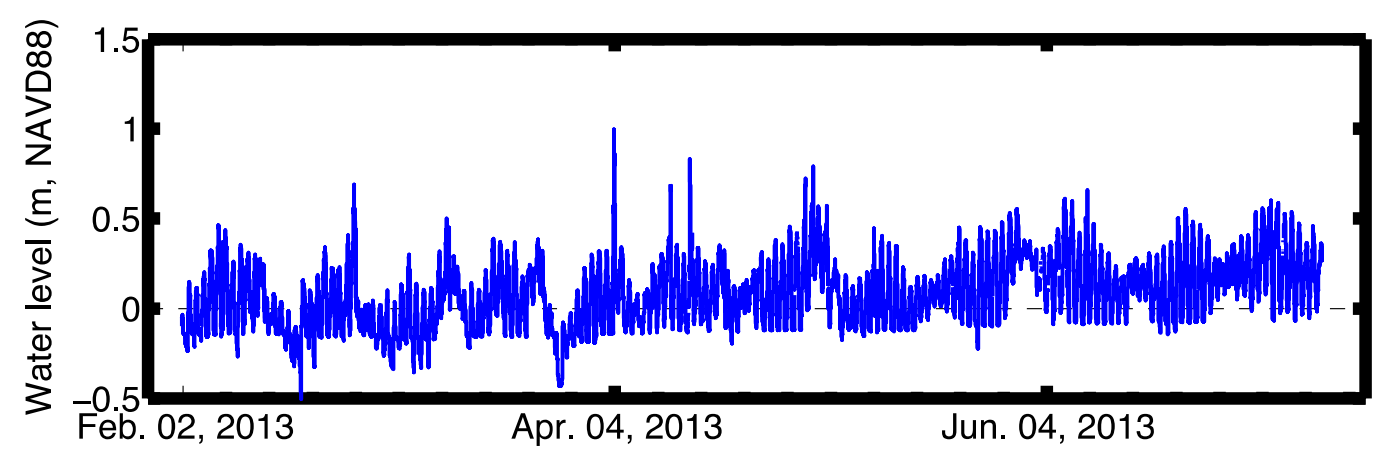

Figure 14. Water level time series from an RBR DR1060 pressure logger mounted in a buried well at Site 948, Chandeleur Islands, Louisiana, from February 1 through July 16, 2013. m, meters; NAVD88, North American Vertical Datum of 1988. 


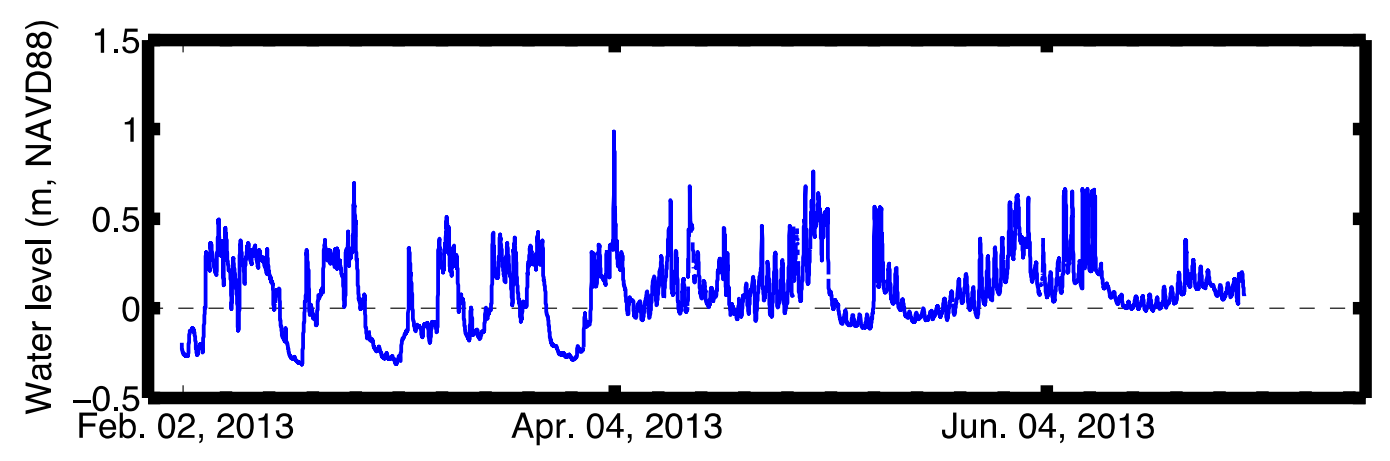

Figure 15. Water level time series from an Onset Hobo U20 pressure logger mounted in a buried well at Site 949 Chandeleur Islands, Louisiana, from February 1 through July 16, 2013. m, meters; NAVD88, North American Vertical Datum of 1988. 


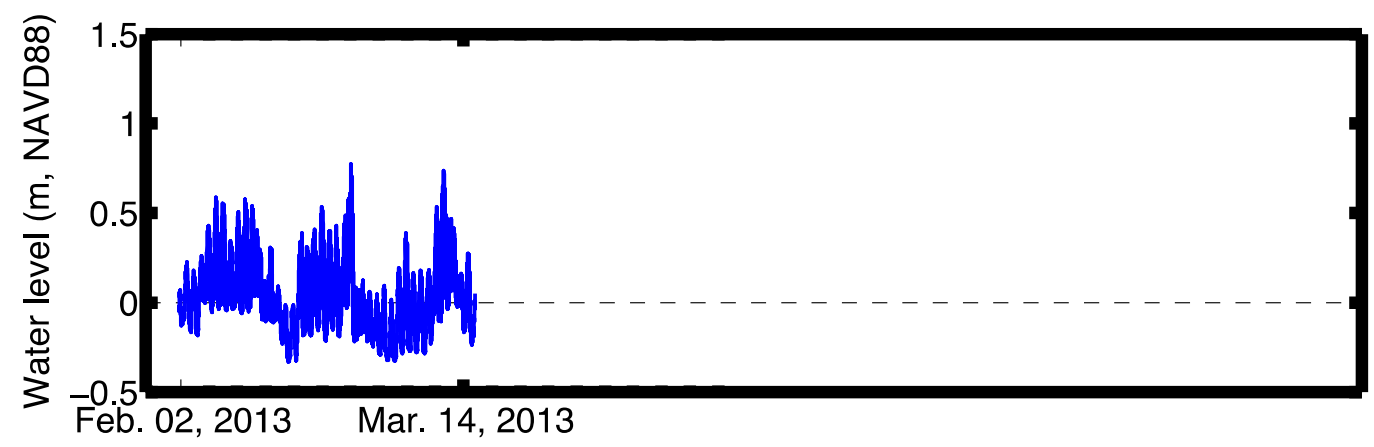

Figure 16. Water level time series from an RBR DR1060 pressure logger mounted in a buried well at Site 950, Chandeleur Islands, Louisiana, from February 1 through March 15, 2013. The data record ends on March 15, 2013, when the instrument was discovered on the beach by a fisherman and removed. m, meters; NAVD88, North American Vertical Datum of 1988. 

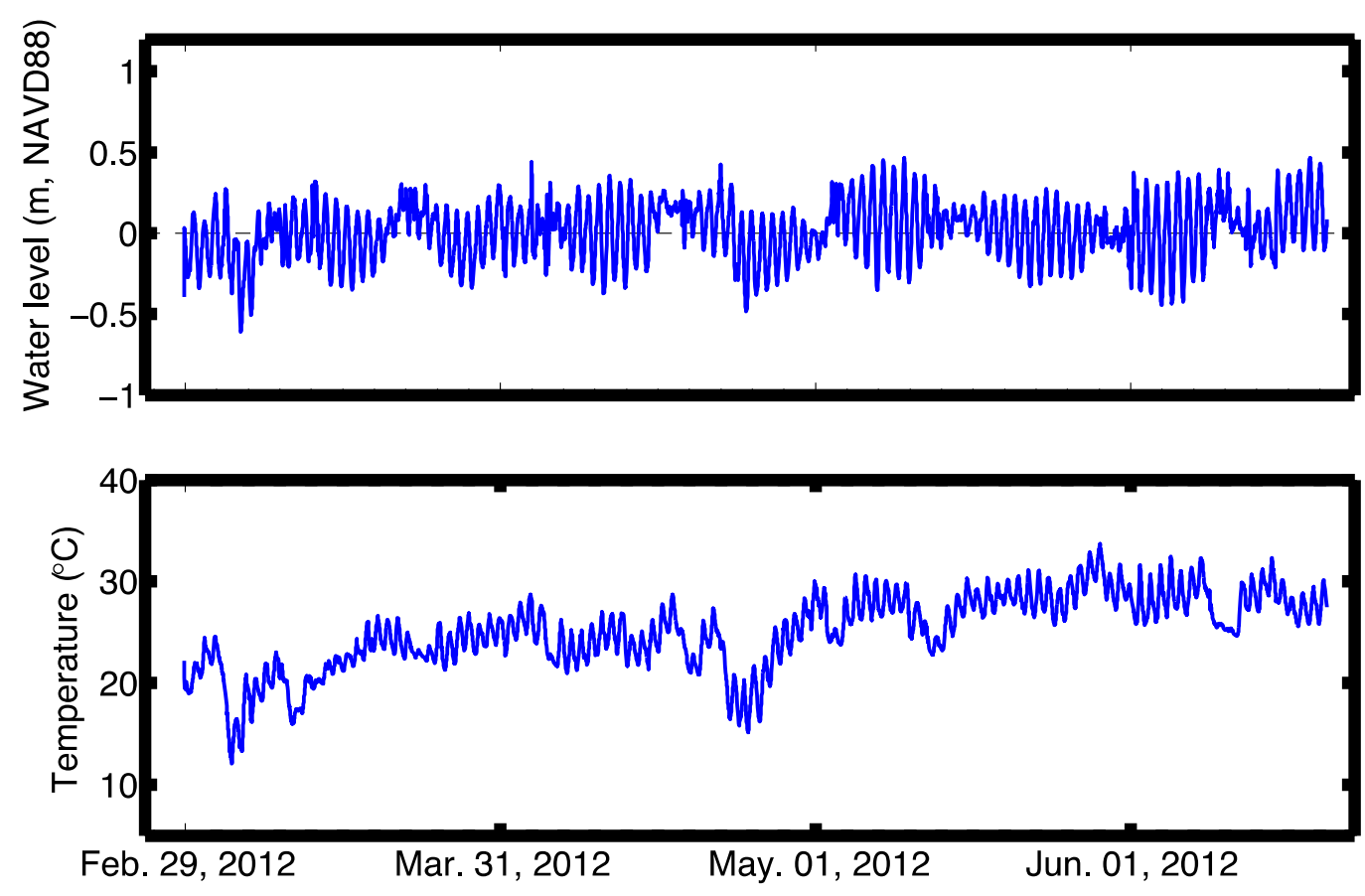

Figure 17. Water level and temperature time series from a Sea-Bird SBE 26 deployed at the Pelican site in the Chandeleur Islands, Louisiana, from February 28, 2012, to June 20, 2012. m, meters; NAVD88, North American Vertical Datum of $1988 ;{ }^{\circ} \mathrm{C}$, degrees Celsius. 

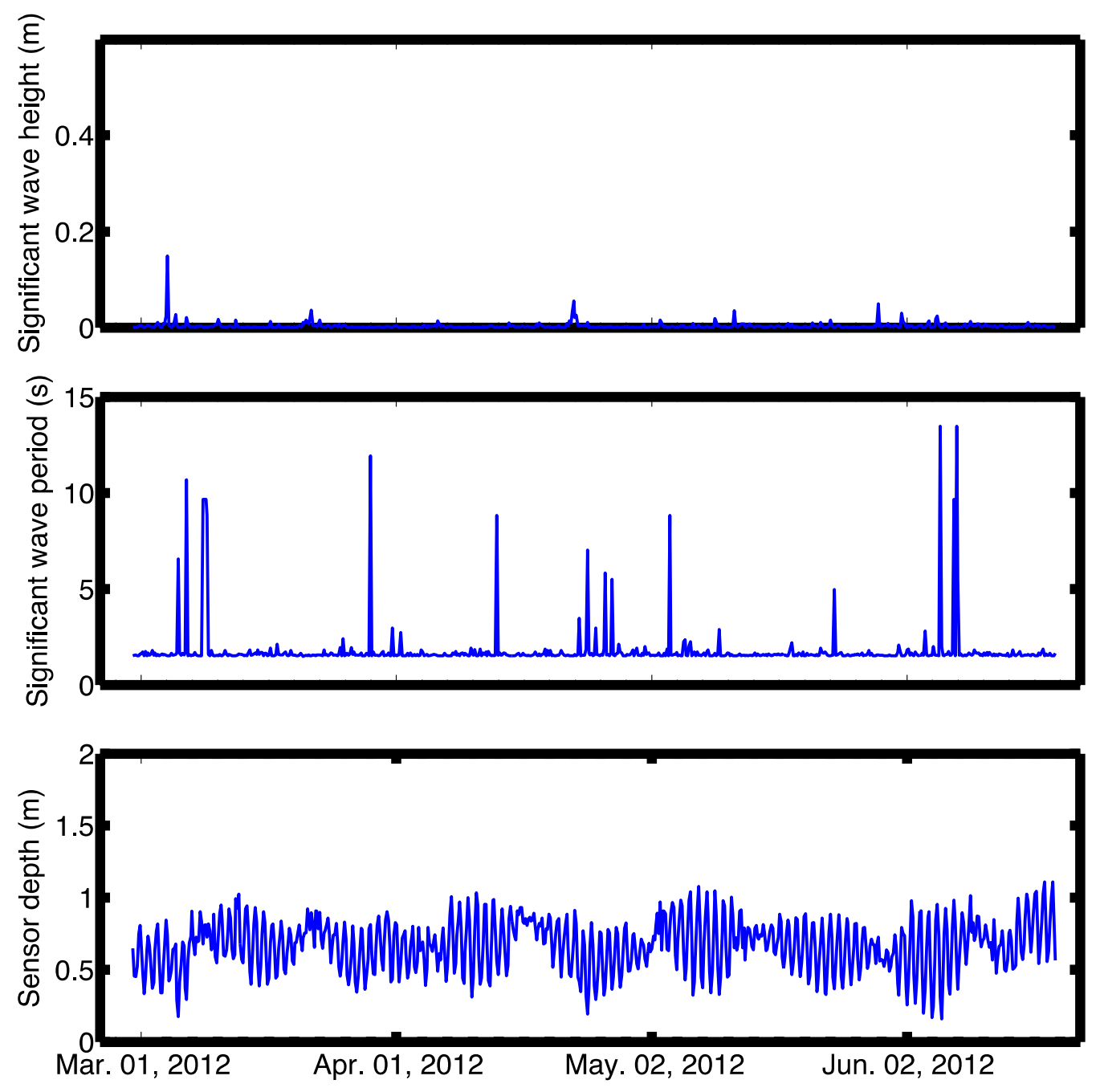

Figure 18. Wave statistics and sensor depth time series from a Sea-Bird SBE 26 deployed at the Pelican site in the Chandeleur Islands, Louisiana, from February 28, 2012, to June 20, 2012. m, meters; s, seconds. 

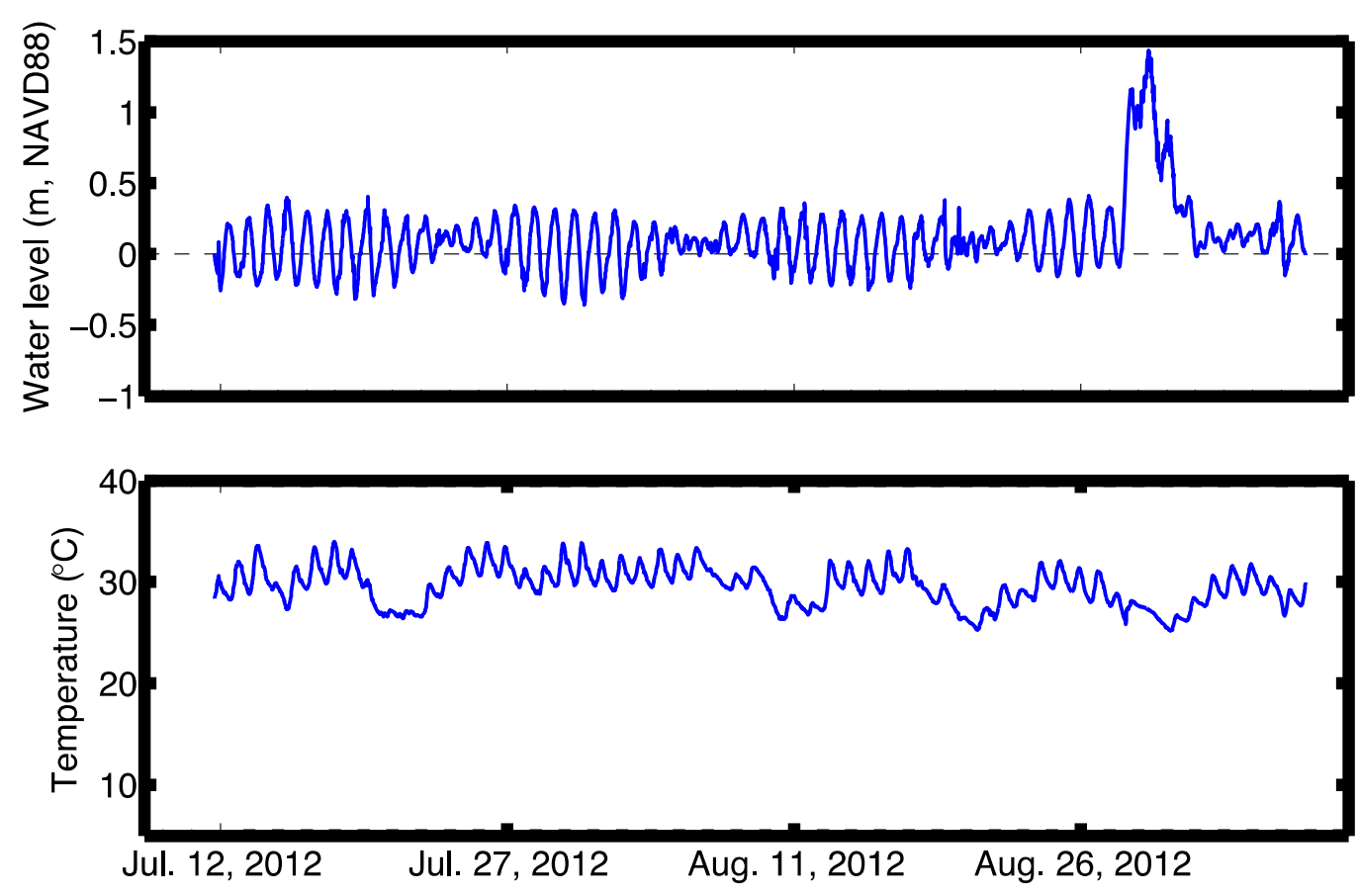

Figure 19. Water level and temperature time series from a Sea-Bird SBE 26 deployed at the Pelican site in the Chandeleur Islands, Louisiana, from July 11, 2012, to September 6, 2012. The passage of Hurricane Isaac is evident on August 29 and 30. m, meters; NAVD88, North American Vertical Datum of 1988 ; ${ }^{\circ} \mathrm{C}$, degrees Celsius. 

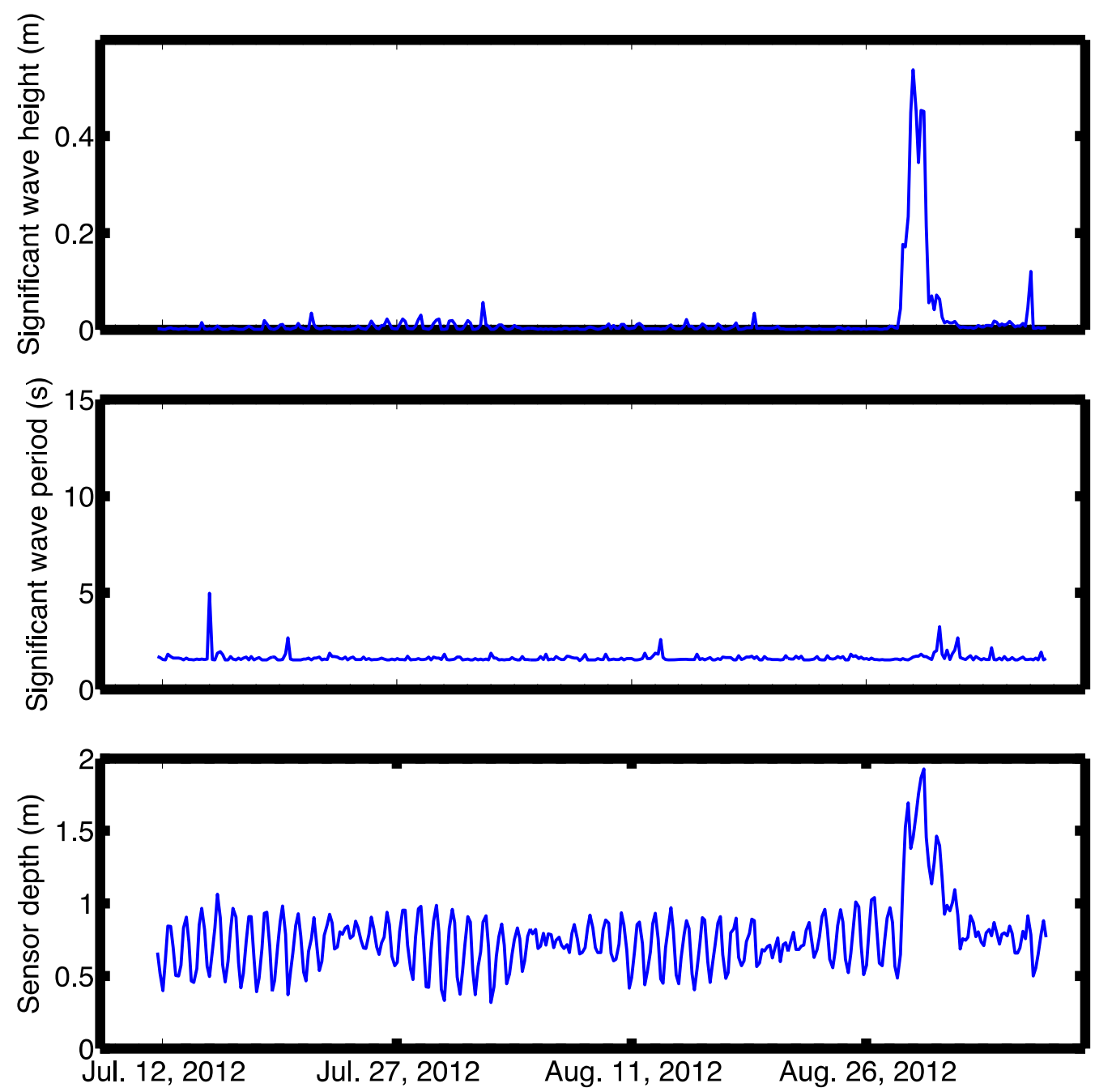

Figure 20. Wave statistics and time series of sensor depth relative to sea surface from a Sea-Bird SBE 26 deployed at the Pelican site in the Chandeleur Islands, Louisiana, from July 11, 2012, to September 6, 2012. The passage of Hurricane Isaac is evident on August 29 and 30. m, meters; s, seconds. 

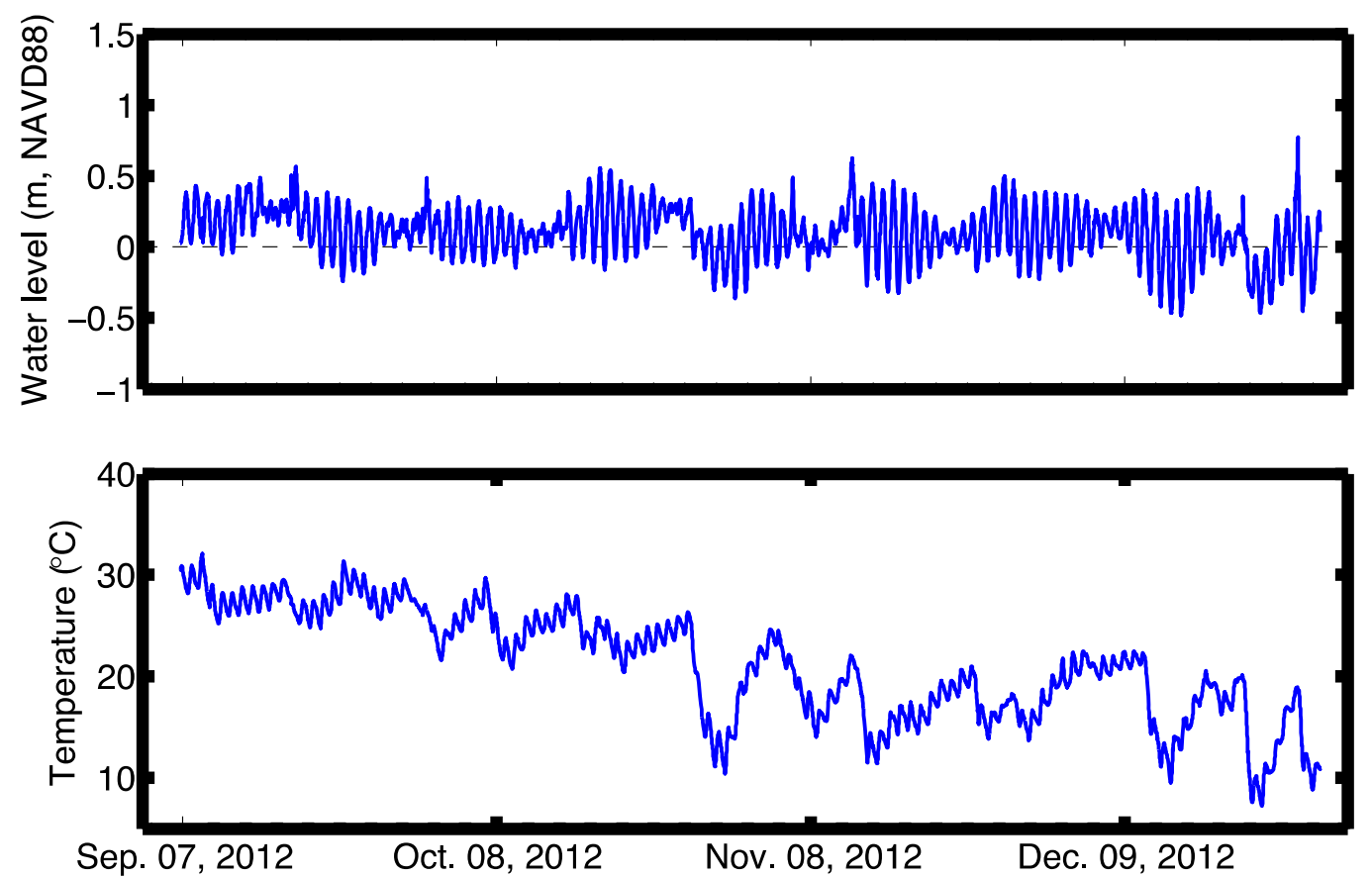

Figure 21. Water level and temperature time series from a Sea-Bird SBE 26 deployed at the Pelican site in the Chandeleur Islands, Louisiana, from September 6, 2012, to December 28, 2012. m, meters; NAVD88, North American Vertical Datum of $1988 ;{ }^{\circ} \mathrm{C}$, degrees Celsius. 

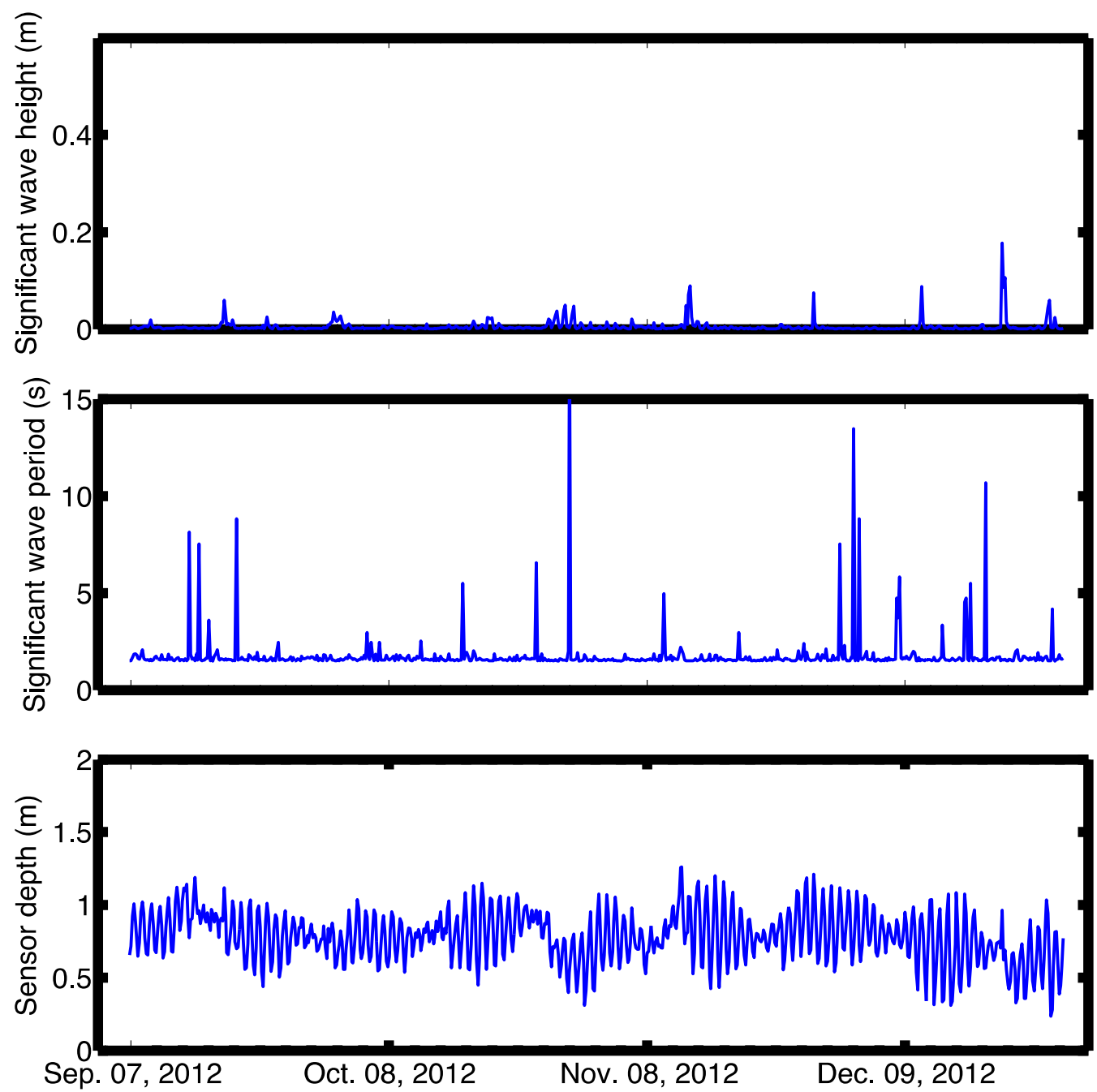

Figure 22. Wave statistics and time series of sensor depth relative to sea surface from a Sea-Bird SBE 26 deployed at the Pelican site in the Chandeleur Islands, Louisiana, from September 6, 2012, to December 28, 2012. $\mathrm{m}$, meters; s, seconds. 

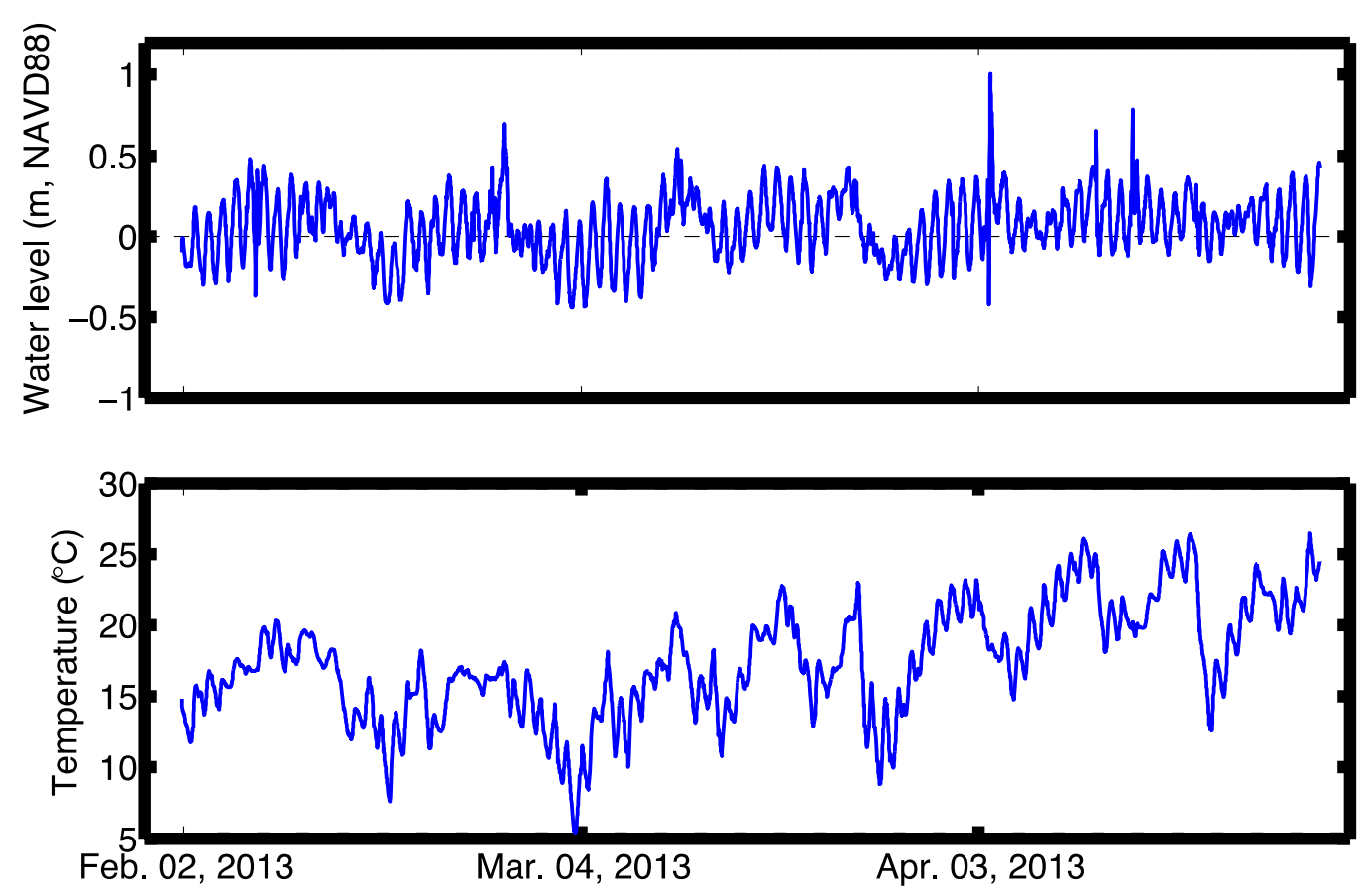

Figure 23. Water level and temperature time series from a Sea-Bird SBE 26 deployed at the Pelican site in the Chandeleur Islands, Louisiana, from February 1, 2013, to April 28, 2013. m, meters; NAVD88, North American Vertical Datum of $1988 ;{ }^{\circ} \mathrm{C}$, degrees Celsius. 

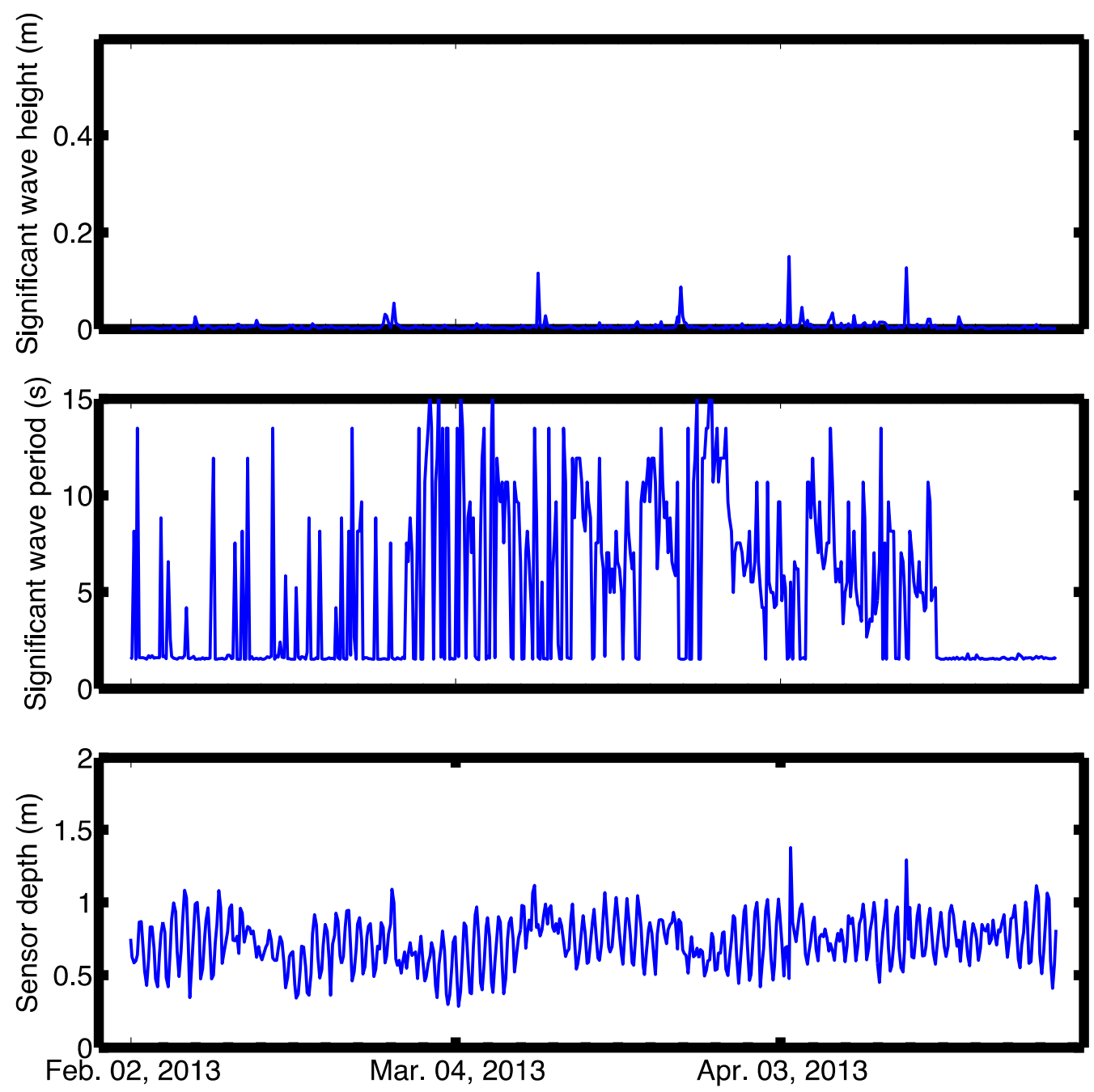

Figure 24. Wave statistics and time series of sensor depth relative to sea surface from a Sea-Bird SBE 26 deployed at the Pelican site in the Chandeleur Islands, Louisiana, from February 1, 2013, to April 28, 2013. m, meters; s, seconds. 

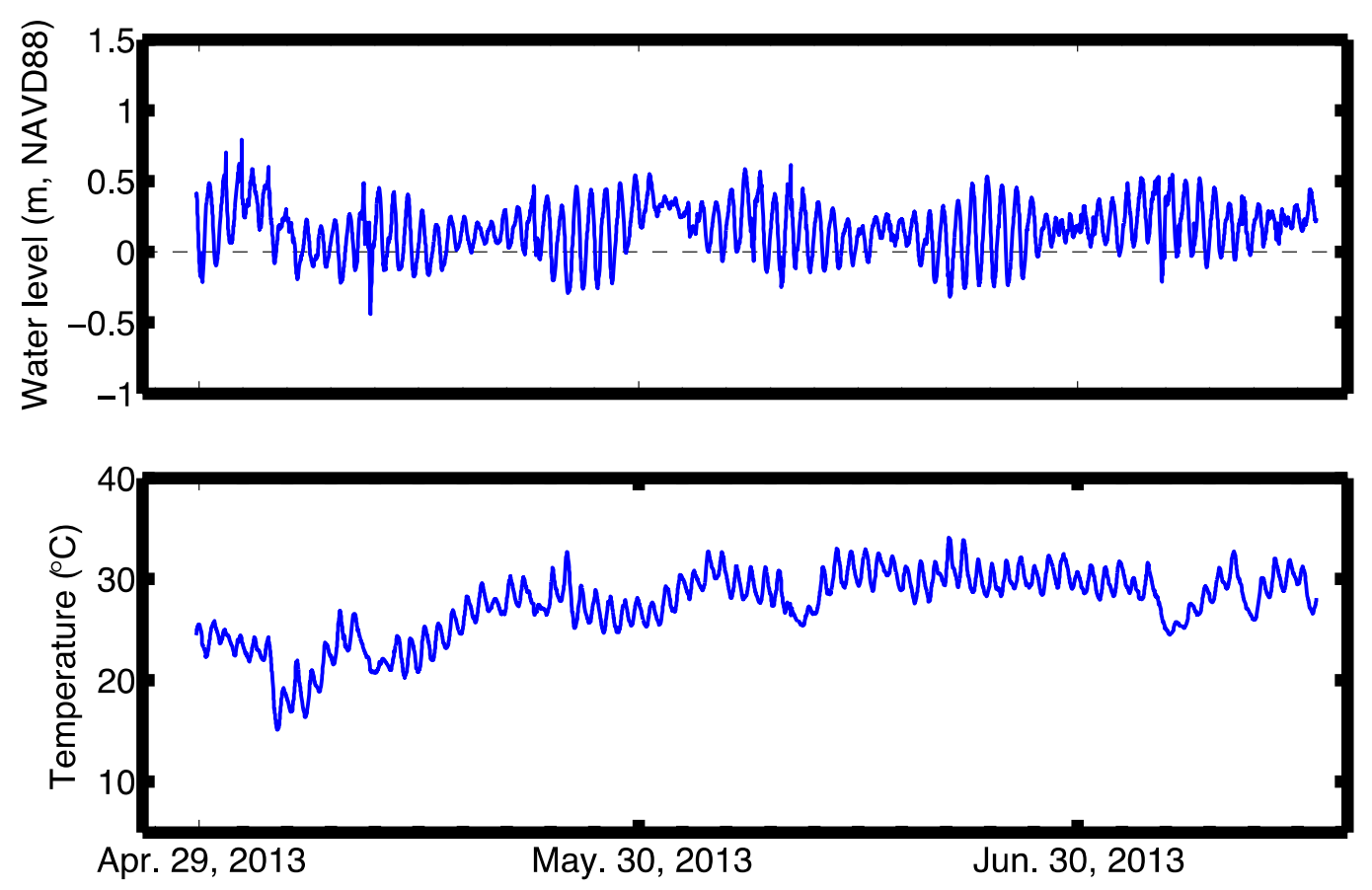

Figure 25. Water level and temperature time series from a Sea-Bird SBE 26 deployed at the Pelican site in the Chandeleur Islands, Louisiana, from April 28, 2013, to July 16, 2013. m, meters; NAVD88, North American Vertical Datum of $1988 ;{ }^{\circ} \mathrm{C}$, degrees Celsius. 

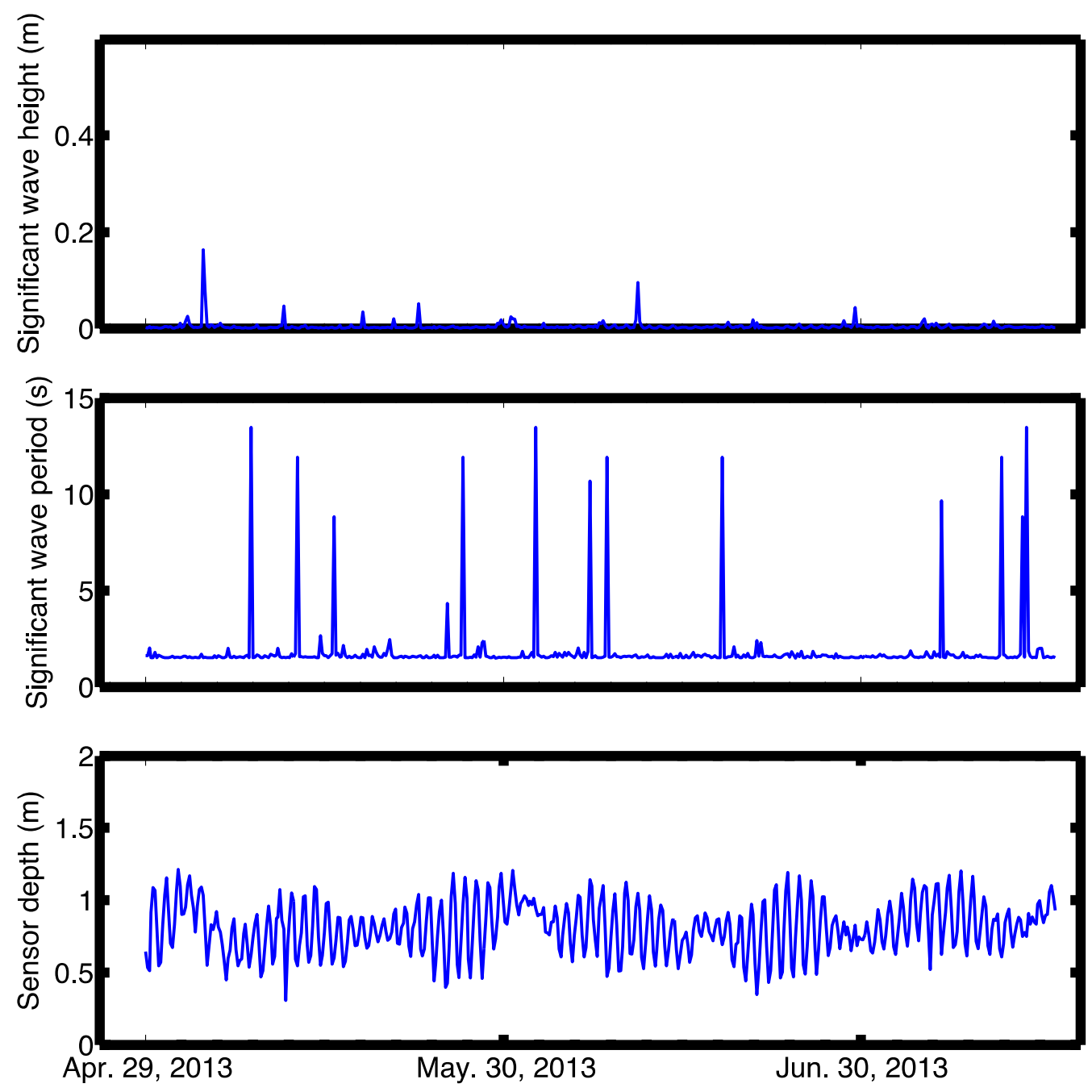

Figure 26. Wave statistics and time series of sensor depth relative to sea surface from a Sea-Bird SBE 26 deployed at the Pelican site in the Chandeleur Islands, Louisiana, from April 28, 2013, to July 16, 2013. m, meters; $\mathrm{s}$, seconds. 

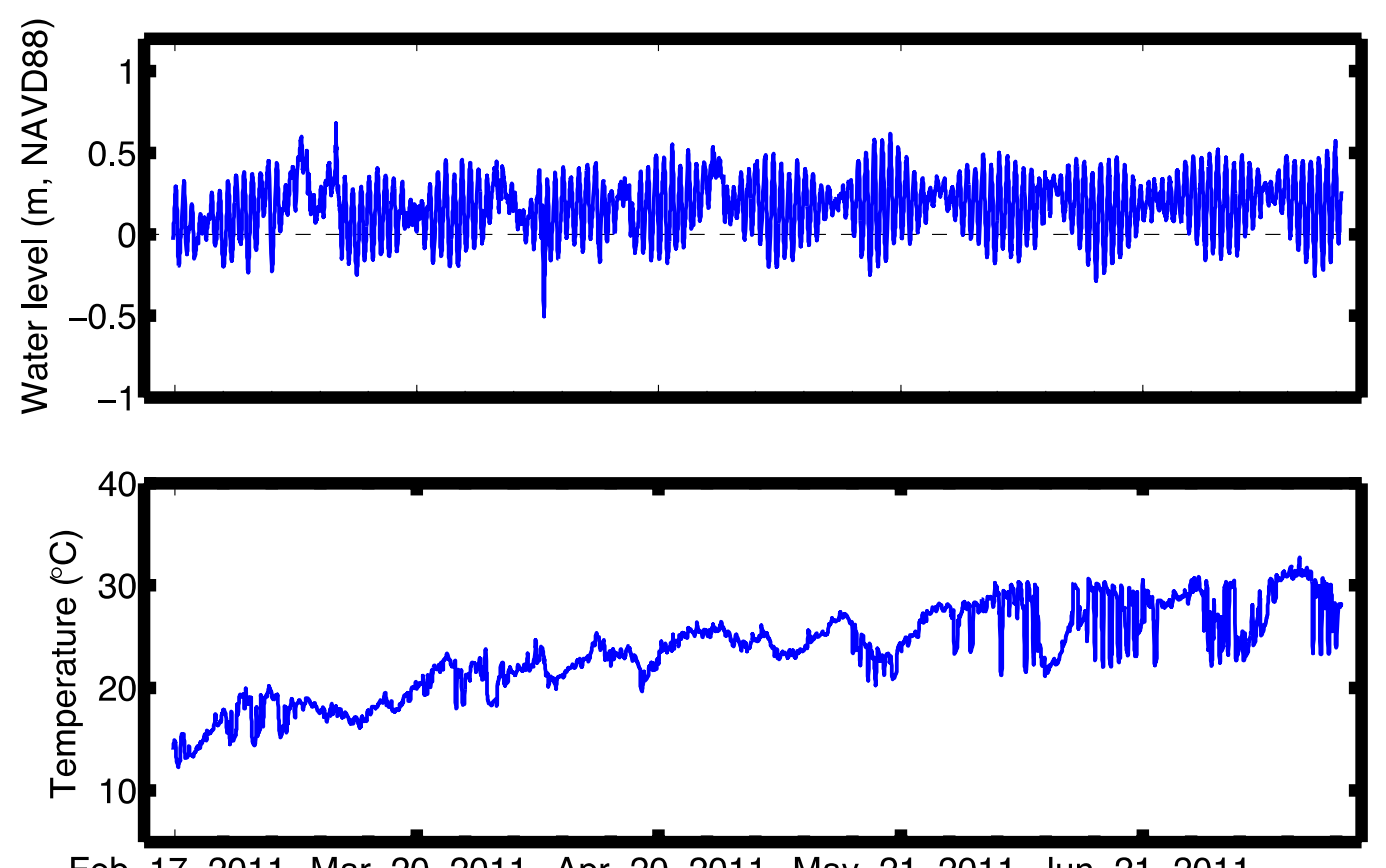

Feb. 17, 2011 Mar. 20, 2011 Apr. 20, 2011 May. 21, 2011 Jun. 21, 2011

Figure 27. Water level and temperature time series from a Sea-Bird SBE 26+ deployed at the Tower site in the Chandeleur Islands, Louisiana, from February 16, 2011, to July 16, 2011. m, meters; NAVD88, North American Vertical Datum of $1988 ;{ }^{\circ} \mathrm{C}$, degrees Celsius. 

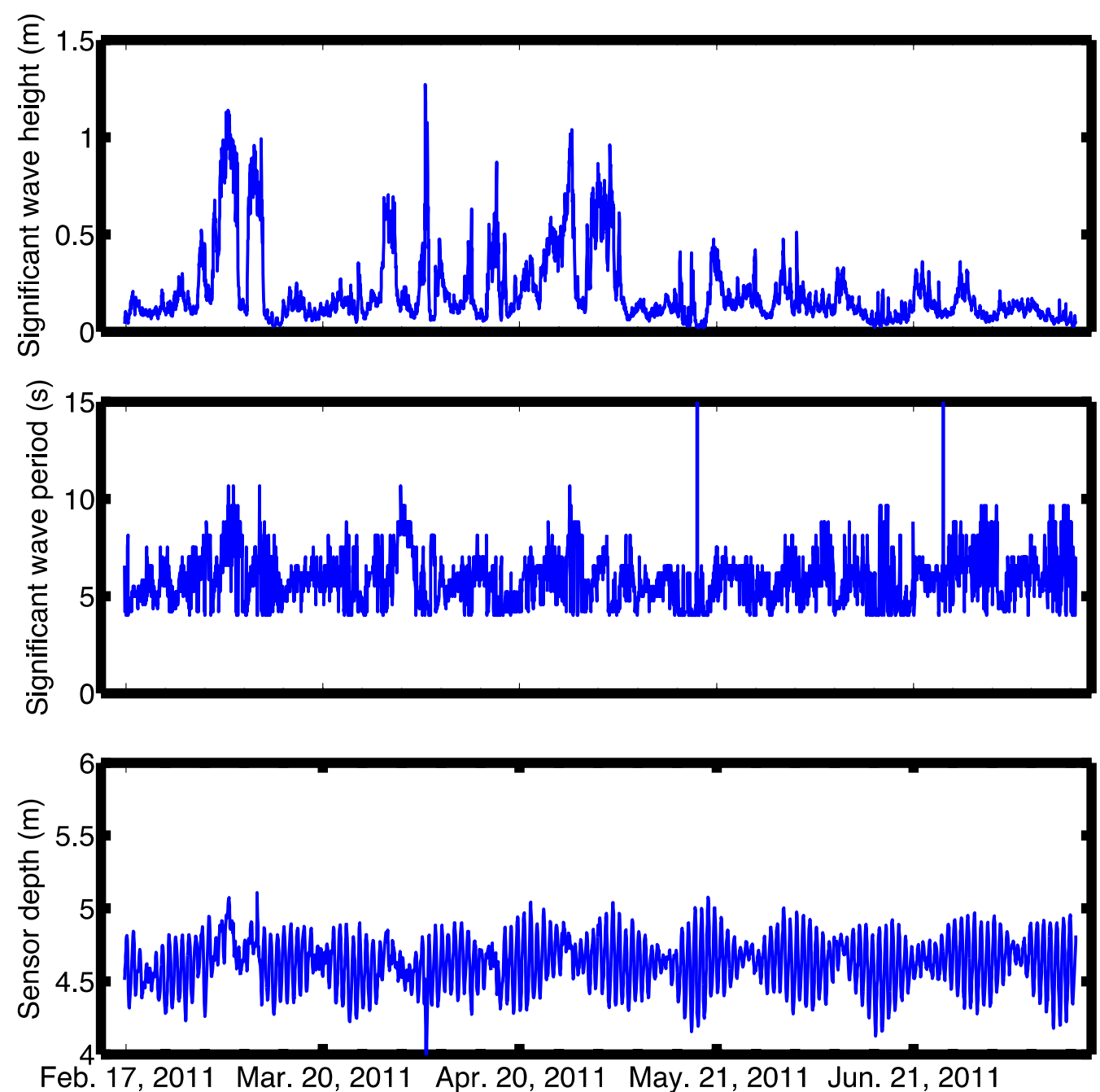

Figure 28. Wave statistics and time series of sensor depth relative to sea surface from a Sea-Bird SBE 26+ deployed at the Tower site in the Chandeleur Islands, Louisiana, from February 16, 2011, to July 16, 2011. m, meters; s, seconds. 

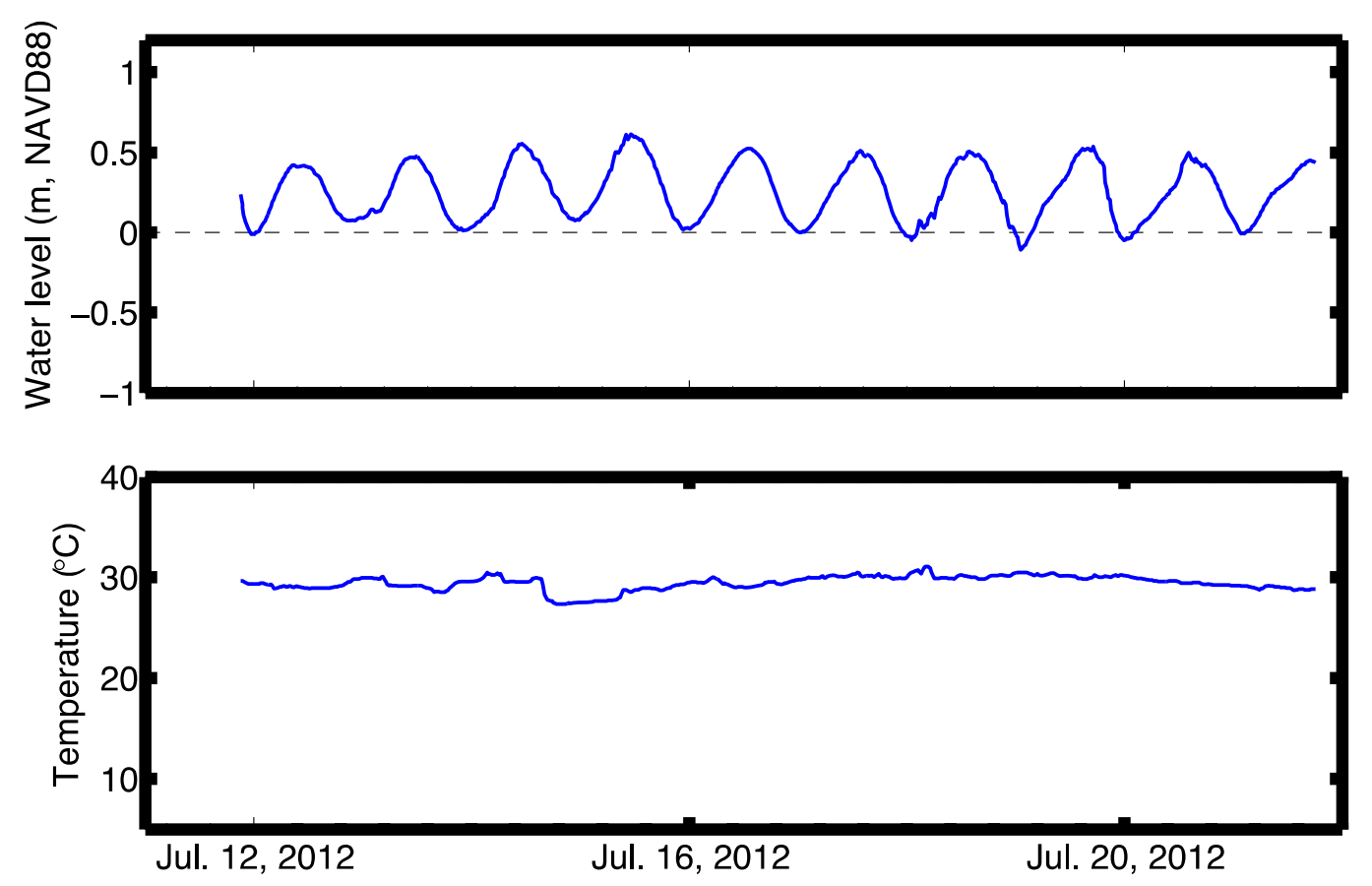

Figure 29. Water level and temperature time series from a Sea-Bird SBE 26 deployed at the Tower site in the Chandeleur Islands, Louisiana, from July 11, 2012, to July 21, 2012. m, meters; NAVD88, North American Vertical Datum of $1988 ;{ }^{\circ} \mathrm{C}$, degrees Celsius. 

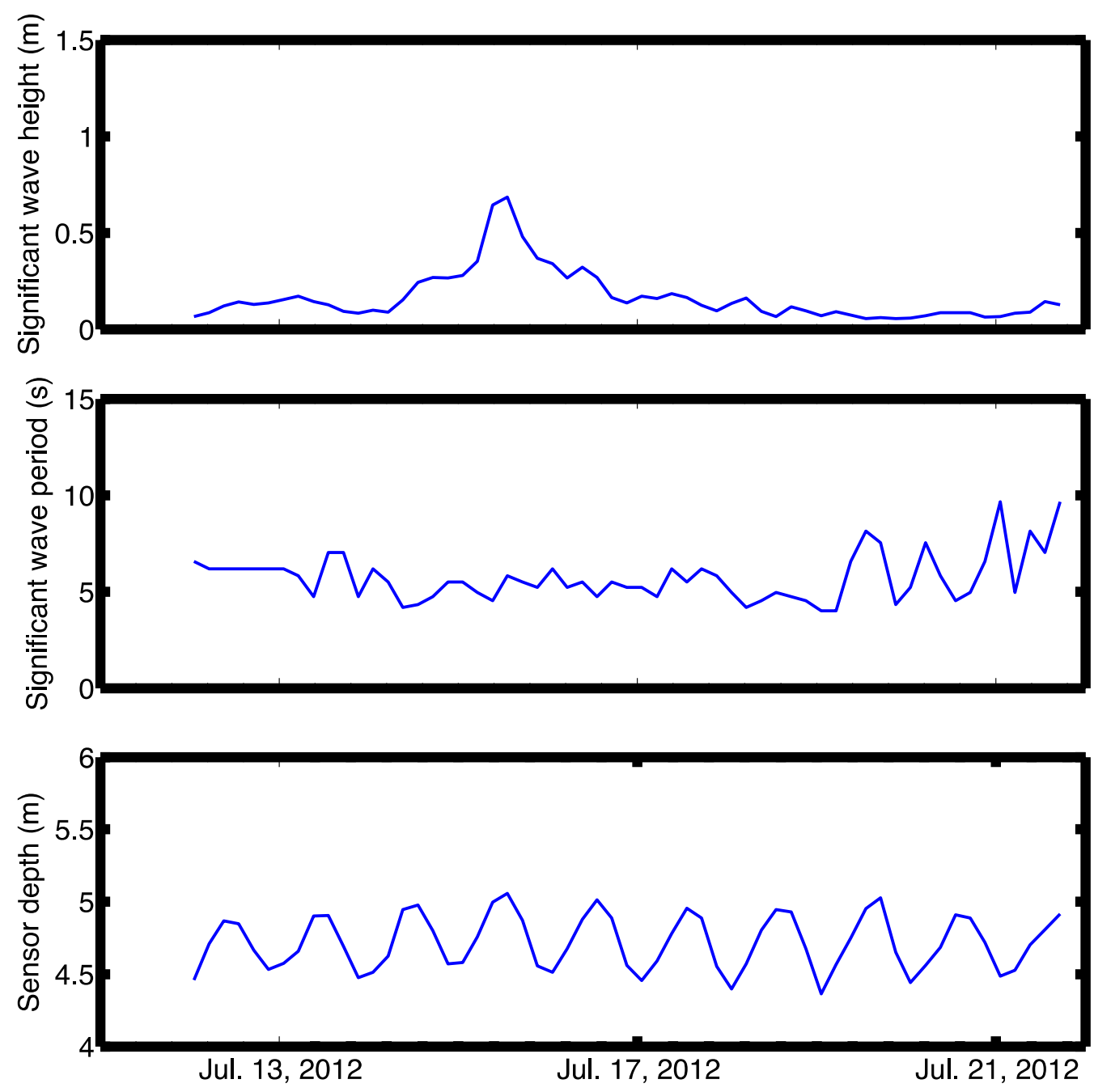

Figure 30. Wave statistics and time series of sensor depth relative to sea surface from a Sea-Bird SBE 26 deployed at the Tower site in the Chandeleur Islands, Louisiana, from July 11, 2012, to July 21,2012 . m, meters; s, seconds. 

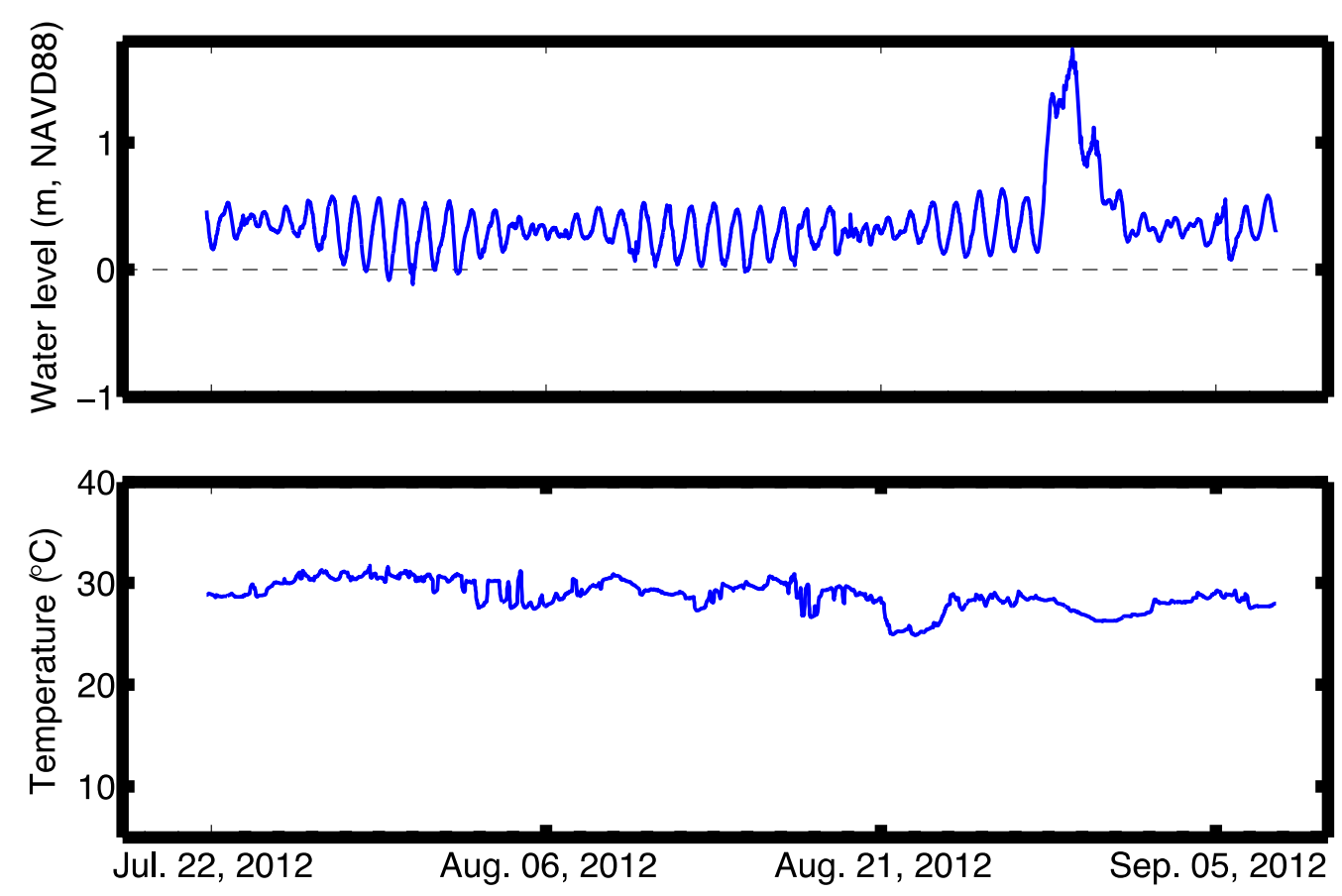

Figure 31. Water level and temperature time series from a Sea-Bird SBE 26 deployed at the Tower site in the Chandeleur Islands, Louisiana, from July 21, 2012, to September 7, 2012. m, meters; NAVD88, North American Vertical Datum of $1988 ;{ }^{\circ} \mathrm{C}$, degrees Celsius. 

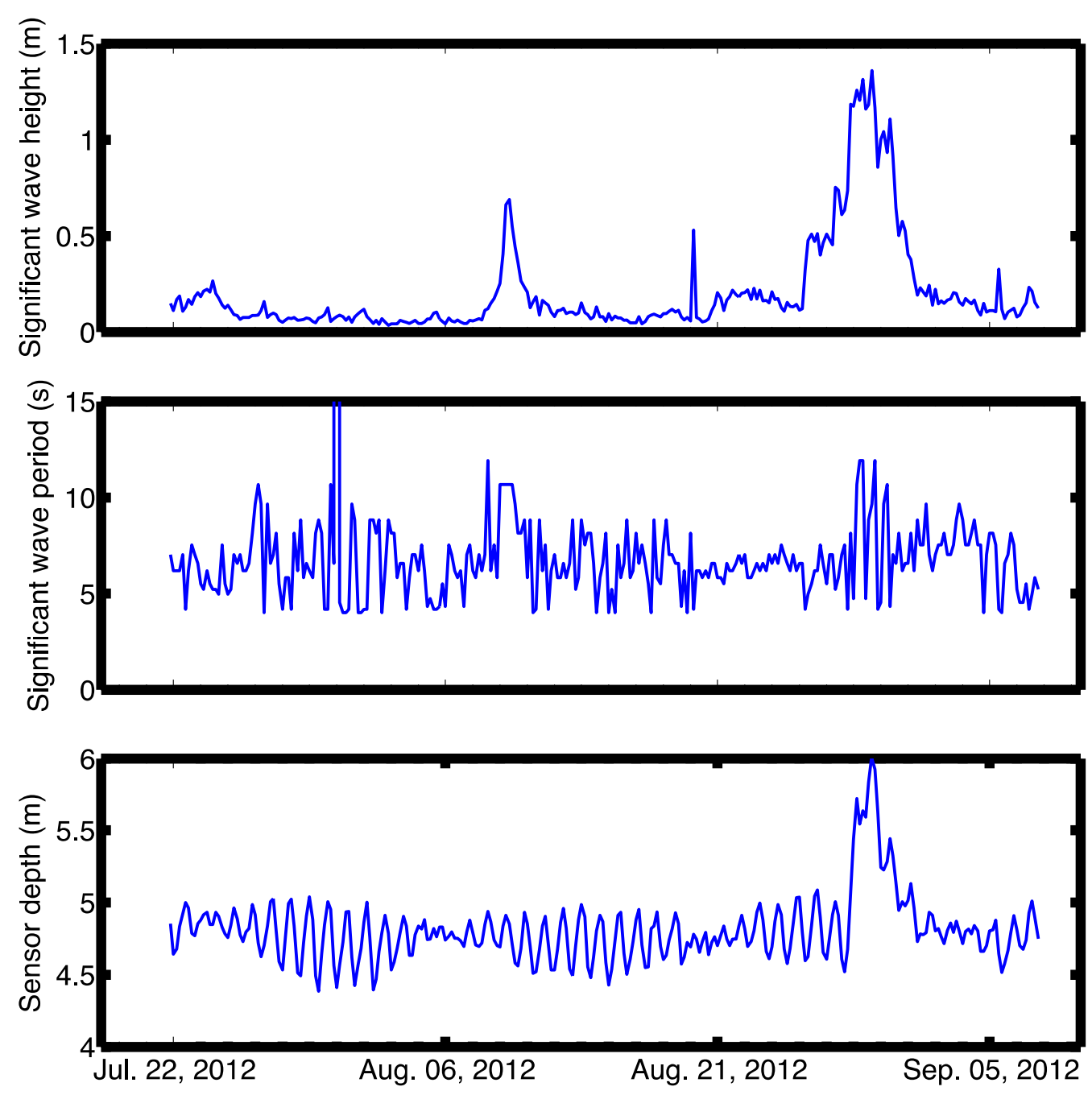

Figure 32. Wave statistics and time series of sensor depth relative to sea surface from a Sea-Bird SBE 26 deployed at the Tower site in the Chandeleur Islands, Louisiana, from July 21, 2012, to September 7, 2012. m, meters; s, seconds. 

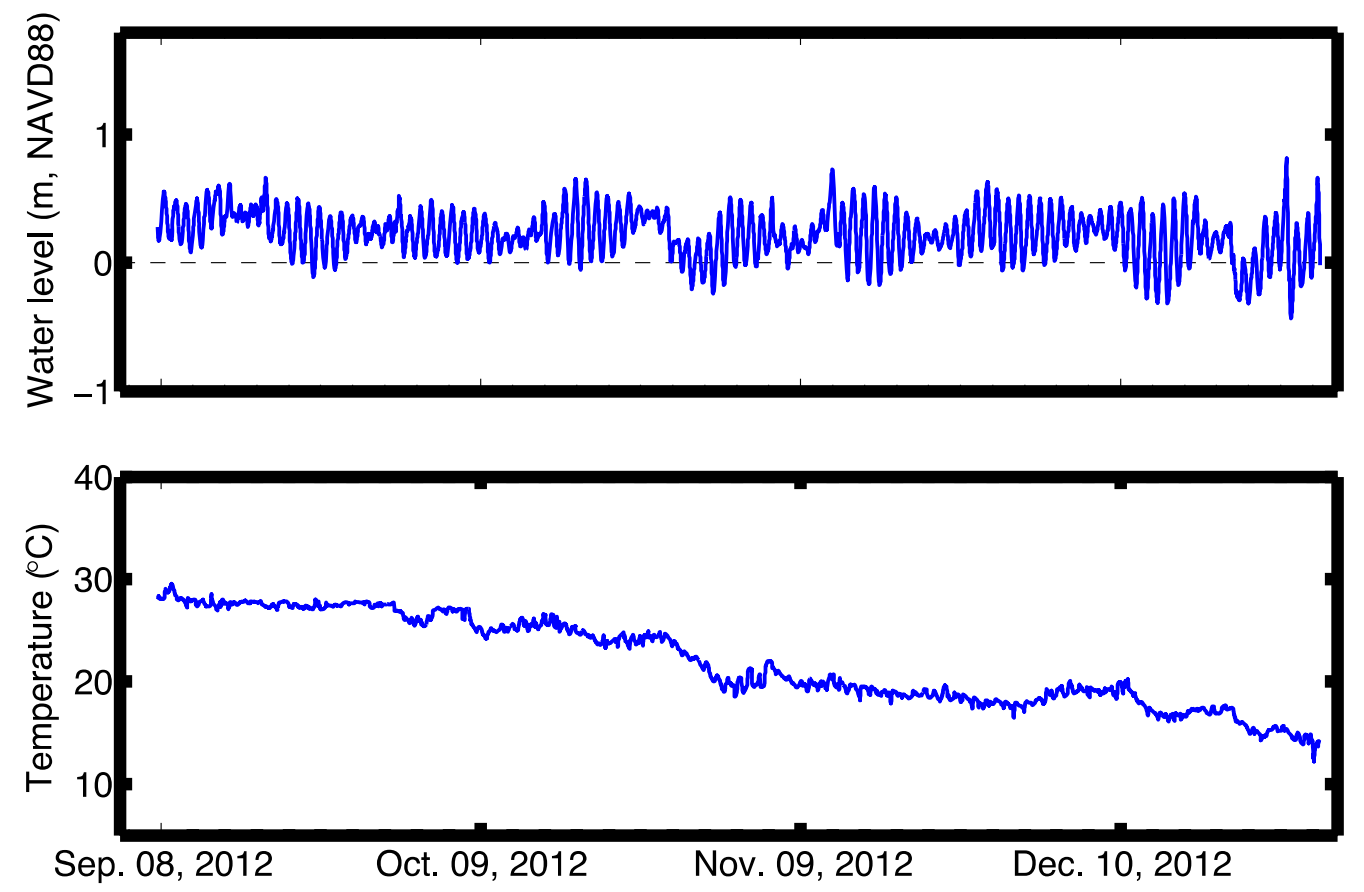

Figure 33. Water level and temperature time series from a Sea-Bird SBE 26 deployed at the Tower site in the Chandeleur Islands, Louisiana, from September 7, 2012, to December 29, 2012. m, meters; NAVD88, North American Vertical Datum of 1988 ; ${ }^{\circ} \mathrm{C}$, degrees Celsius. 

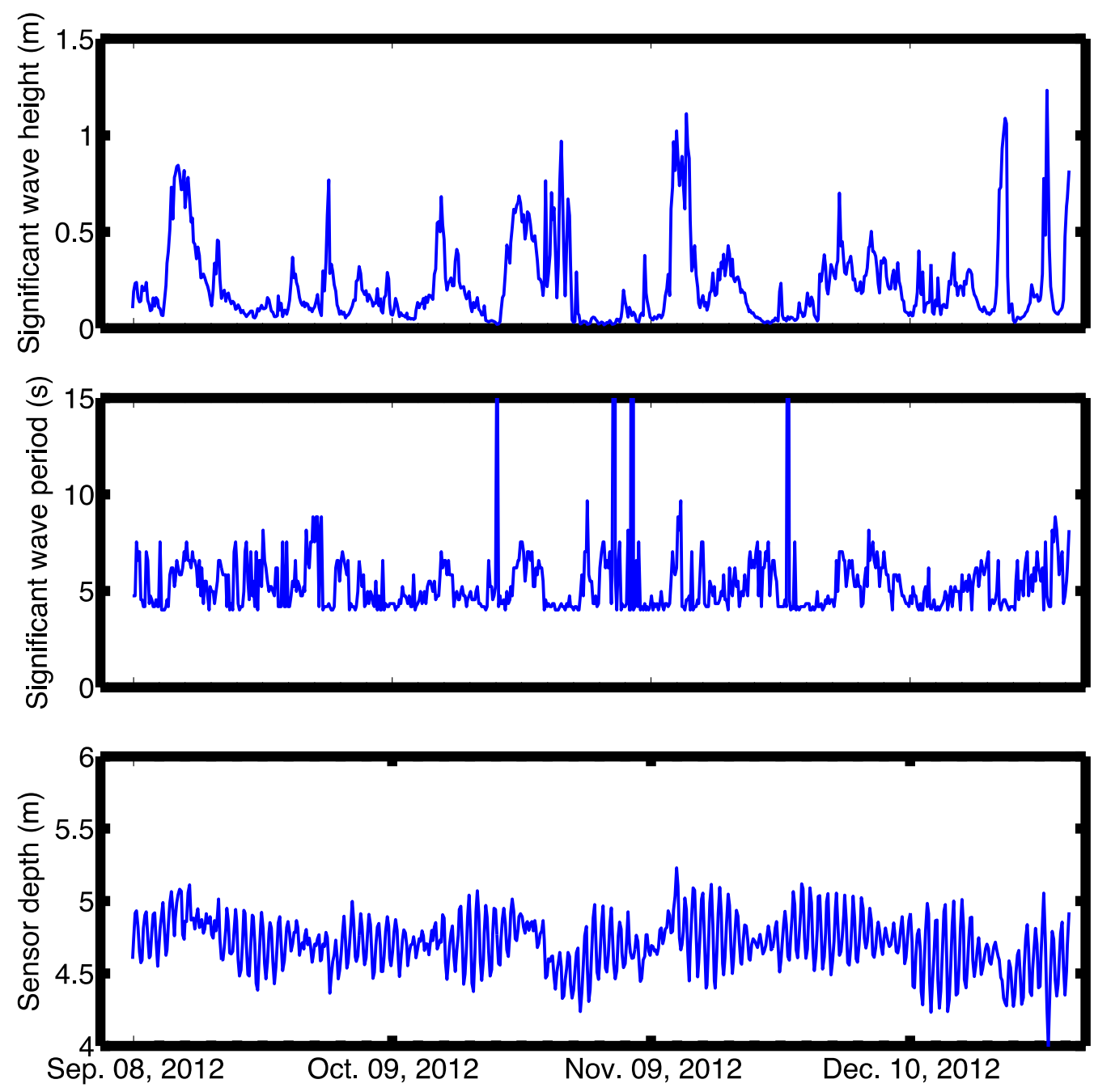

Figure 34. Wave statistics and time series of sensor depth relative to sea surface from a Sea-Bird SBE 26 deployed at the Tower site in the Chandeleur Islands, Louisiana, from September 7, 2012, to December 29, 2012. $\mathrm{m}$, meters; s, seconds. 

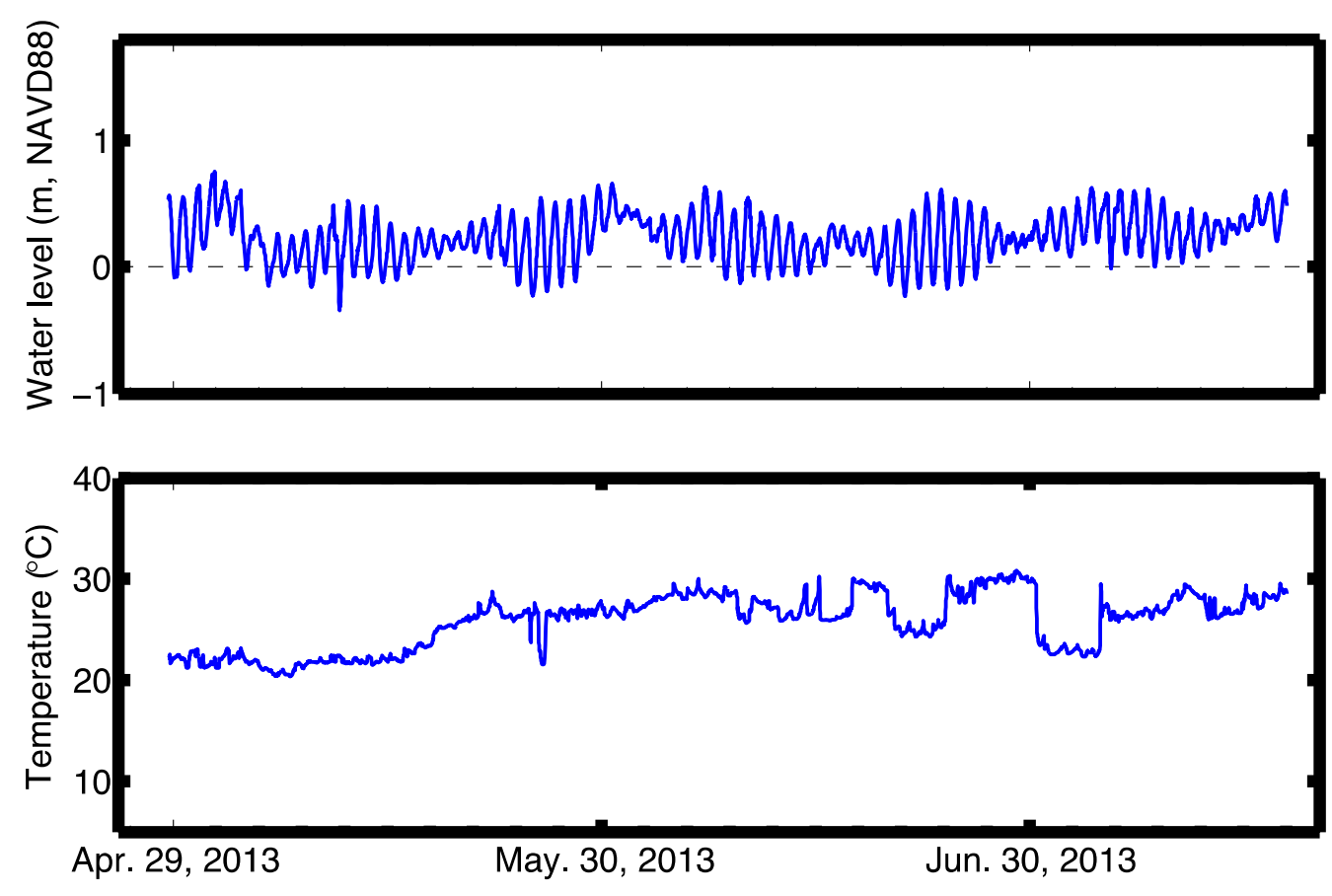

Figure 35. Water level and temperature time series from a Sea-Bird SBE 26 deployed at the Tower site in the Chandeleur Islands, Louisiana, from January 31, 2013, to April 28, 2013. m, meters; NAVD88, North American Vertical Datum of $1988 ;{ }^{\circ} \mathrm{C}$, degrees Celsius. 

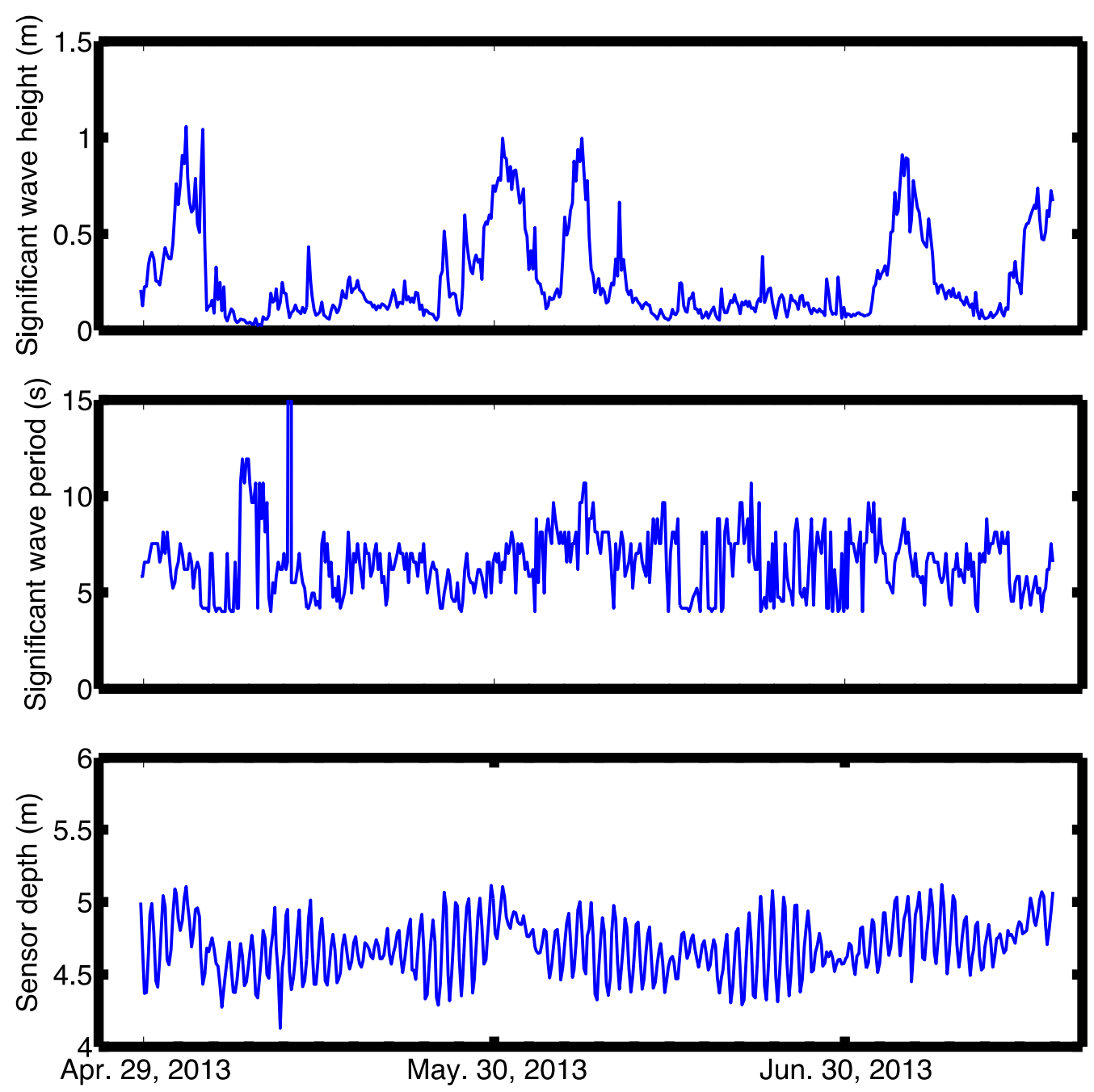

Figure 36. Wave statistics and time series of sensor depth relative to sea surface from a Sea-Bird SBE 26 deployed at the Tower site in the Chandeleur Islands, Louisiana, from January 31, 2013, to April 28, 2013. m, meters; s, seconds. 

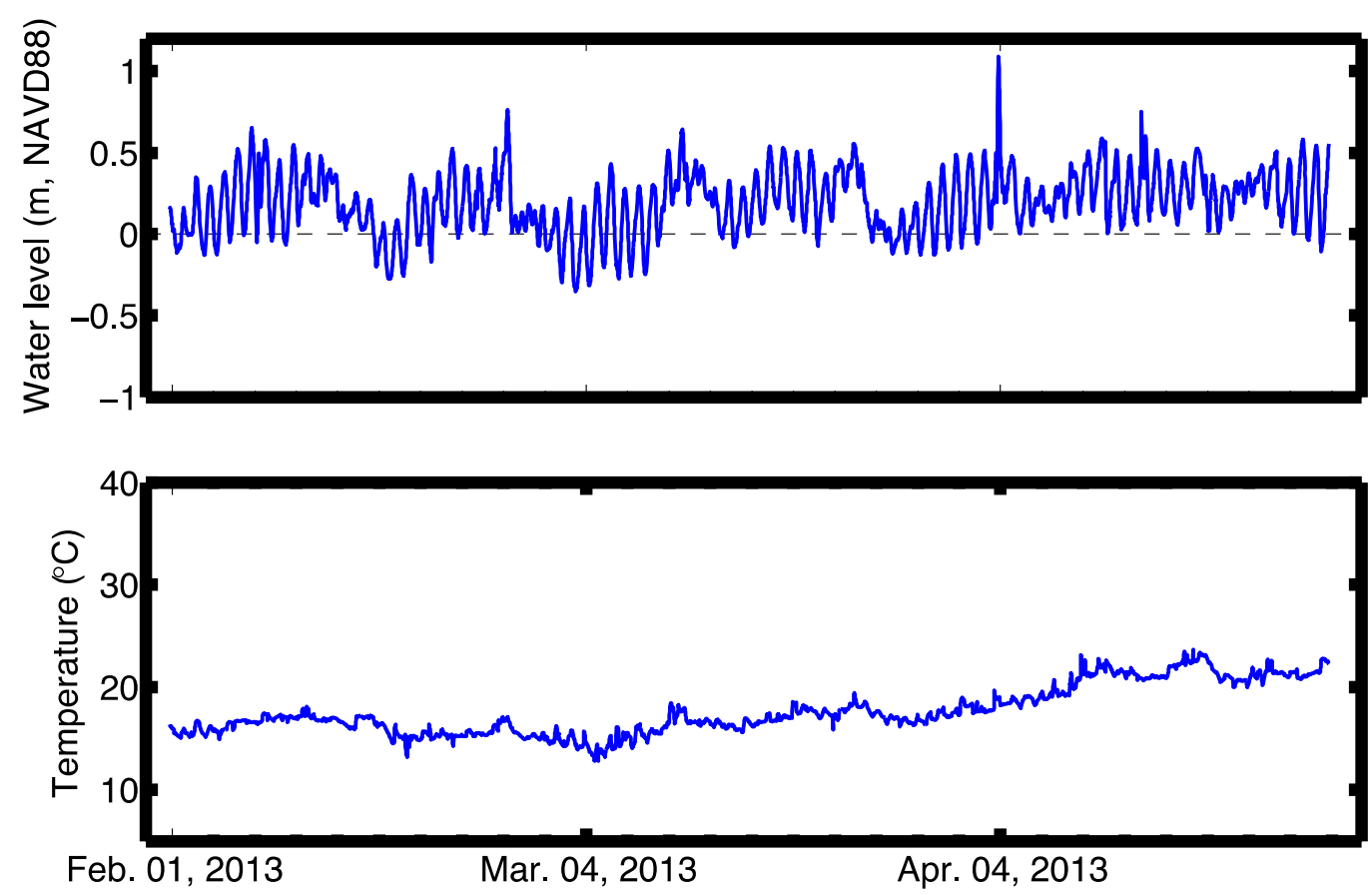

Figure 37. Water level and temperature time series from a Sea-Bird SBE 26 deployed at the Tower site in the Chandeleur Islands, Louisiana, from April 28, 2013, to July 18, 2013. m, meters; NAVD88, North American Vertical Datum of $1988 ;{ }^{\circ} \mathrm{C}$, degrees Celsius. 

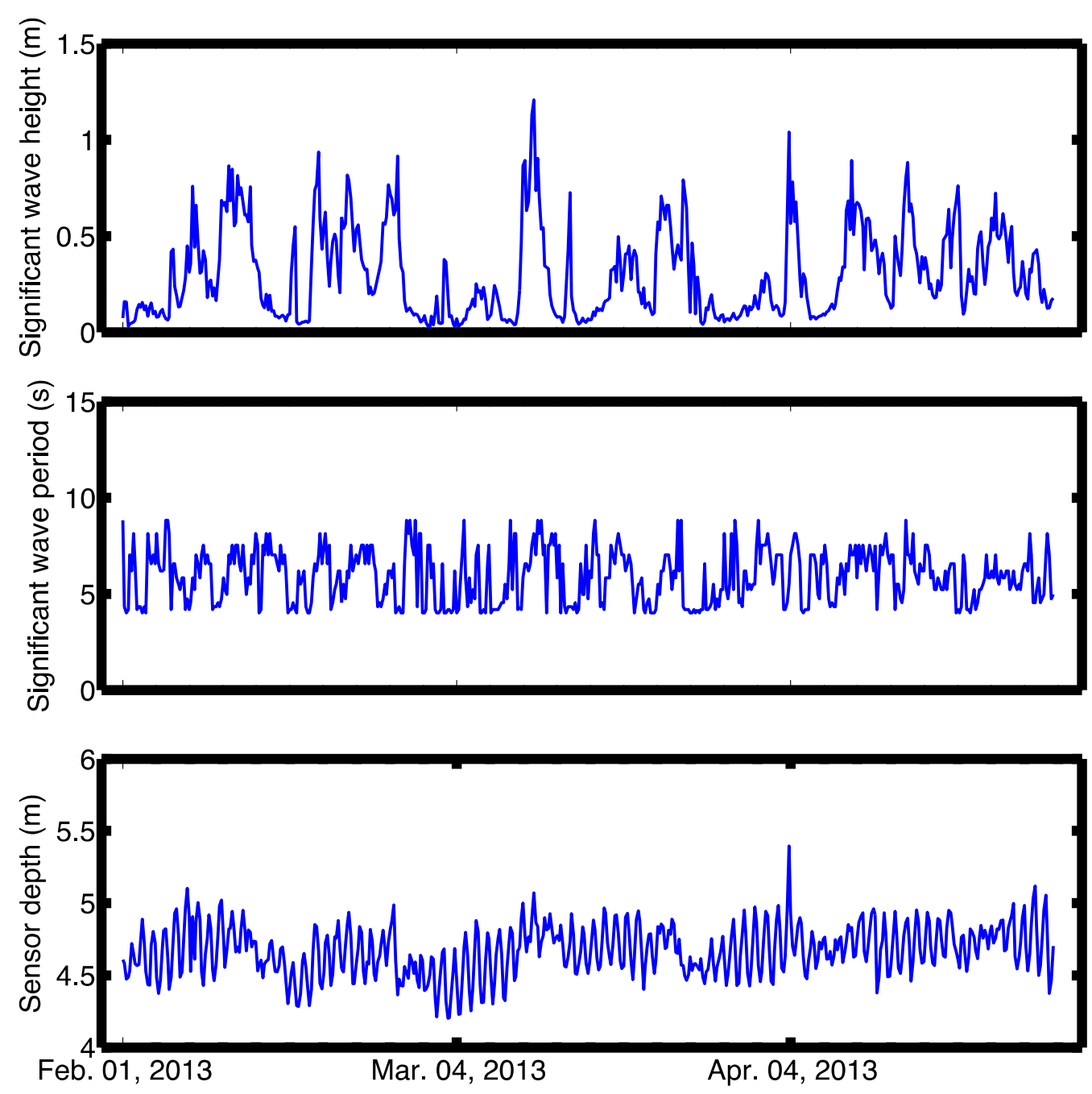

Figure 38. Wave statistics and time series of sensor depth relative to sea surface from a Sea-Bird SBE 26 deployed at the Tower site in the Chandeleur Islands, Louisiana, from April 28, 2013, to July 18, 2013. m, meters; s, seconds. 


\section{Tables}

Table 1 Mooring log sensor, location, and deployment information

[NAVD88, North American Vertical Datum of 1988; N, north; W, west; UTC, Coordinated Universal Time; NA, not available]

\begin{tabular}{|c|c|c|c|c|c|c|c|c|c|c|}
\hline Sensor type & Measurement type & Serial number & $\begin{array}{c}\text { Mooring } \\
\text { number or } \\
\text { site name }\end{array}$ & $\begin{array}{c}\begin{array}{c}\text { Sensor } \\
\text { elevation }\end{array} \\
\text { (meters above } \\
\text { NAVD88) }\end{array}$ & $\begin{array}{l}\text { Sensor elevation } \\
\text { uncertainty (meters } \\
\text { above NAVD88) }\end{array}$ & $\begin{array}{l}\text { Distance } \\
\text { from cap to } \\
\text { sensor } \\
\text { (meters) }\end{array}$ & Latitude N & Longitude W & $\begin{array}{c}\text { Time } \\
\text { deployed, UTC }\end{array}$ & $\begin{array}{c}\text { Time recovered, } \\
\text { UTC }\end{array}$ \\
\hline SBE26 & Water level and waves & 192 & Pelican & -0.628 & NA & NA & 29.9488 & 88.8319 & 2/28/12 21:10 & 6/20/12 8:00 \\
\hline SBE26 & Water level and waves & 217 & Pelican & -0.628 & NA & NA & 29.9488 & 88.8319 & 7/11/12 16:00 & 9/6/12 18:30 \\
\hline SBE26 & Water level and waves & 192 & Pelican & -0.628 & NA & NA & 29.9488 & 88.8319 & 9/6/12 19:50 & $12 / 28 / 128: 40$ \\
\hline SBE26 & Water level and waves & 217 & Pelican & -0.628 & NA & NA & 29.9488 & 88.8319 & 2/1/13 21:00 & 4/28/13 18:50 \\
\hline SBE26 & Water level and waves & 169 & Pelican & -0.628 & NA & NA & 29.9488 & 88.8319 & 4/28/13 19:00 & 7/16/13 20:00 \\
\hline SBE26+ & Water level and waves & 1099 & Tower & -4.419 & NA & NA & 30.0447 & 88.8774 & 2/16/11 18:30 & 7/16/11 14:30 \\
\hline SBE26 & Water level and waves & 192 & Tower & -4.419 & NA & NA & 30.0447 & 88.8774 & 7/11/12 21:00 & 7/21/12 18:10 \\
\hline SBE26 & Water level and waves & 169 & Tower & -4.419 & NA & NA & 30.0447 & 88.8774 & 7/21/12 19:15 & 9/7/12 16:20 \\
\hline SBE26 & Water level and waves & 217 & Tower & -4.419 & NA & NA & 30.0447 & 88.8774 & 9/7/12 16:40 & 12/29/12 8:40 \\
\hline SBE26 & Water level and waves & 169 & Tower & -4.419 & NA & NA & 30.0447 & 88.8774 & 1/31/13 21:00 & 4/28/13 13:40 \\
\hline SBE26 & Water level and waves & 192 & Tower & -4.419 & NA & NA & 30.0447 & 88.8774 & 4/28/13 15:00 & 7/18/13 15:30 \\
\hline
\end{tabular}




\begin{tabular}{|c|c|c|c|c|c|c|c|c|c|c|}
\hline Sensor type & Measurement type & Serial number & $\begin{array}{l}\text { Mooring } \\
\text { number or } \\
\text { site name }\end{array}$ & $\begin{array}{c}\text { Sensor } \\
\text { elevation } \\
\text { (meters above } \\
\text { NAVD88) }\end{array}$ & $\begin{array}{c}\text { Sensor elevation } \\
\text { uncertainty (meters } \\
\text { above NAVD88) }\end{array}$ & $\begin{array}{l}\text { Distance } \\
\text { from cap to } \\
\text { sensor } \\
\text { (meters) }\end{array}$ & Latitude N & Longitude W & $\begin{array}{c}\text { Time } \\
\text { deployed, UTC }\end{array}$ & $\begin{array}{c}\text { Time recovered, } \\
\text { UTC }\end{array}$ \\
\hline $\begin{array}{l}\text { RBR } \\
\text { DR1060 }\end{array}$ & Water level & 24032 & 942 & -0.395 & 0.016 & 0.797 & 29.94092 & 88.82316 & 7/10/12 17:33 & $9 / 7 / 12$ \\
\hline $\begin{array}{l}\text { RBR } \\
\text { DR1060 }\end{array}$ & Water level & 24033 & 943 & -0.239 & 0.002 & 0.784 & 29.94098 & 88.82166 & 7/10/12 18:18 & $9 / 7 / 12$ \\
\hline $\begin{array}{c}\text { Onset Hobo } \\
\text { U20 }\end{array}$ & Water level & 10137339 & 944 & -0.56 & NA & 0.688 & 29.99034 & 88.83492 & 7/11/12 14:13 & Not recovered \\
\hline $\begin{array}{c}\text { Onset Hobo } \\
\text { U20 }\end{array}$ & Water level & 10130440 & 945 & -0.432 & NA & 0.685 & 29.99102 & 88.83314 & 7/11/12 13:38 & Not recovered \\
\hline $\begin{array}{c}\text { Onset Hobo } \\
\text { U20 }\end{array}$ & Atmospheric pressure & 10125471 & 946 / Tower & 4 & NA & NA & 30.0447 & 88.8774 & 7/11/12 21:14 & $9 / 7 / 12$ \\
\hline $\begin{array}{c}\text { Onset Hobo } \\
\text { U20 }\end{array}$ & Atmospheric pressure & 10125471 & 947 / Tower & 4 & NA & NA & 30.0447 & 88.8774 & 9/7/12 13:00 & 1/31/13 20:30 \\
\hline $\begin{array}{l}\text { RBR } \\
\text { DR1060 }\end{array}$ & Water level & 24032 & 948 & -0.924 & 0.013 & 0.797 & 29.9397 & 88.82784 & 2/1/13 19:51 & 7/16/13 17:35 \\
\hline $\begin{array}{c}\text { Onset Hobo } \\
\text { U20 }\end{array}$ & Water level & 10079949 & 949 & -1.049 & 0.009 & 1.306 & 29.94072 & 88.82256 & 2/1/13 19:09 & 7/16/13 18:05 \\
\hline $\begin{array}{l}\text { RBR } \\
\text { DR1060 }\end{array}$ & Water level & 24033 & 950 & -0.801 & NA & 0.784 & 29.94092 & 88.82153 & 2/1/13 18:37 & $3 / 15 / 13$ \\
\hline $\begin{array}{c}\text { Onset Hobo } \\
\text { U20 }\end{array}$ & Atmospheric pressure & 10125471 & 951 / Tower & 4 & NA & NA & 30.0447 & 88.8774 & 2/1/13 22:12 & 7/18/13 14:00 \\
\hline
\end{tabular}


Table 2 Settings used in Sea-Bird Seasoft for Waves version 2.0 to process data from Sea-Bird Seagauges.

$\left[{ }^{\circ} \mathrm{C}\right.$, degrees Celsius; PSU, practical salinity unit]

\begin{tabular}{|c|c|c|c|c|c|c|c|c|c|}
\hline Location & $\begin{array}{c}\text { Height of } \\
\text { pressure } \\
\text { sensor } \\
\text { from } \\
\text { bottom } \\
\text { (meters) }\end{array}$ & $\begin{array}{l}\text { Average water } \\
\text { temperature } \\
\text { above the } \\
\text { pressure sensor } \\
\left.\text { ( }{ }^{\circ} \mathrm{C}\right)\end{array}$ & $\begin{array}{c}\text { Average } \\
\text { salinity } \\
\text { above the } \\
\text { pressure } \\
\text { sensor } \\
\text { (PSU) }\end{array}$ & $\begin{array}{l}\text { Number of } \\
\text { spectral } \\
\text { estimates for } \\
\text { each } \\
\text { frequency } \\
\text { band }\end{array}$ & $\begin{array}{l}\text { Minimum } \\
\text { allowable } \\
\text { attenuation } \\
\text { (default = } \\
0.0025 \text { ) }\end{array}$ & $\begin{array}{l}\text { Minimum } \\
\text { period } \\
\text { (seconds) to } \\
\text { use in auto- } \\
\text { spectrum } \\
\text { (default }=0 \text { ) }\end{array}$ & $\begin{array}{c}\text { Maximum } \\
\text { period } \\
\text { (seconds) to } \\
\text { use in auto- } \\
\text { spectrum } \\
\text { (default = } \\
\text { 1e6) }\end{array}$ & $\begin{array}{l}\text { Hanning } \\
\text { uindow } \\
\text { cutoff } \\
\text { (default = } \\
0.1)\end{array}$ & $\begin{array}{c}\text { Chi-squared } \\
\text { confidence } \\
\text { percent } \\
\text { (default = 90) }\end{array}$ \\
\hline Pelican & 0.85 & 24 & 34 & 5 & 0.0025 & 1.5 & 15 & 0.1 & 90 \\
\hline Tower & 0.85 & 24 & 34 & 5 & 0.0025 & 4 & $1.00 \mathrm{E}+06$ & 0.1 & 90 \\
\hline
\end{tabular}


Table 3. Instrumentation and data files for measurements of atmospheric pressure and temperature, water level, and waves, Chandeleur Islands, Louisiana, 2012 to 2013.

[UTC, Coordinated Universal Time]

\begin{tabular}{|c|c|c|c|c|c|}
\hline Sensor type & Serial number & $\begin{array}{c}\text { Mooring number or site } \\
\text { name }\end{array}$ & Start of data record, UTC & End of data record, UTC & Data file name \\
\hline \multicolumn{6}{|c|}{ Atmospheric pressure and temperature measurements } \\
\hline $\begin{array}{l}\text { Onset Hobo U20 } \\
\text { Onset Hobo U20 } \\
\text { Onset Hobo U20 }\end{array}$ & $\begin{array}{l}10125471 \\
10125471 \\
10125471 \\
\end{array}$ & $\begin{array}{l}946 \text { / Tower } \\
947 \text { / Tower } \\
951 \text { / Tower }\end{array}$ & $\begin{array}{c}7 / 11 / 12 \text { 21:20:00 } \\
\text { 9/7/12 17:06:08 } \\
\text { 2/1/13 22:20:00 } \\
\end{array}$ & $\begin{array}{c}\text { 9/7/12 16:10:00 } \\
\text { 1/31/13 20:26:08 } \\
7 / 01 / 13 \text { 21:40:00 }\end{array}$ & $\begin{array}{c}\text { 9461hwl-a.nc } \\
\text { 9471hwl.nc } \\
\text { 9511hwl.nc } \\
\end{array}$ \\
\hline \multicolumn{6}{|c|}{ Water-level measurements } \\
\hline $\begin{array}{c}\text { SBE26 } \\
\text { SBE26 } \\
\text { SBE26 } \\
\text { SBE26 } \\
\text { SBE26 } \\
\text { SBE26+ } \\
\text { SBE26 } \\
\text { SBE26 } \\
\text { SBE26 } \\
\text { SBE26 } \\
\text { SBE26 } \\
\text { RBR DR1060 } \\
\text { RBR DR1060 } \\
\text { RBR DR1060 } \\
\text { Onset Hobo U20 } \\
\text { RBR DR1060 } \\
\end{array}$ & $\begin{array}{c}192 \\
217 \\
192 \\
217 \\
169 \\
1099 \\
192 \\
169 \\
217 \\
169 \\
192 \\
24032 \\
24033 \\
24032 \\
10079949 \\
24033 \\
\end{array}$ & $\begin{array}{c}\text { Pelican } \\
\text { Pelican } \\
\text { Pelican } \\
\text { Pelican } \\
\text { Pelican } \\
\text { Tower } \\
\text { Tower } \\
\text { Tower } \\
\text { Tower } \\
\text { Tower } \\
\text { Tower } \\
942 \\
943 \\
948 \\
949 \\
950 \\
\end{array}$ & $\begin{array}{c}2 / 28 / 12 \text { 21:10:15 } \\
\text { 7/11/12 16:05:37 } \\
\text { 9/6/12 18:58:12 } \\
\text { 2/1/13 21:12:19 } \\
\text { 4/28/13 19:12:06 } \\
\text { 2/16/11 18:40:00 } \\
\text { 7/11/12 21:06:34 } \\
\text { 7/21/12 18:55:35 } \\
\text { 9/7/12 16:40:20 } \\
\text { 1/31/13 20:10:04 } \\
\text { 4/28/13 15:05:18 } \\
7 / 10 / 1218: 45: 45 \\
7 / 10 / 1218: 43: 40 \\
\text { 2/1/13 19:51:55 } \\
2 / 1 / 13 \text { 19:10:00 } \\
\text { 2/1/13 18:39:55 } \\
\end{array}$ & $\begin{array}{c}\text { 6/20/12 7:30:15 } \\
\text { 9/6/12 18:25:36 } \\
\text { 12/28/12 7:18:12 } \\
\text { 4/28/13 18:32:18 } \\
7 / 16 / 13 \text { 19:52:07 } \\
\text { 7/16/11 11:00:00 } \\
\text { 7/21/12 18:06:34 } \\
\text { 9/7/12 16:15:34 } \\
\text { 12/29/12 8:20:19 } \\
\text { 4/28/13 13:30:05 } \\
\text { 7/18/13 15:25:19 } \\
\text { 9/7/12 18:37:50 } \\
\text { 9/7/12 20:01:10 } \\
7 / 12 / 13 \text { 21:47:55 } \\
7 / 01 / 13 ~ 21: 50: 00 \\
\text { 3/15/13 14:31:35 } \\
\end{array}$ & $\begin{array}{c}\text { pelican1Asgs-cal.nc } \\
\text { pelican1Bsgs-cal.nc } \\
\text { pelican1Csgs-cal.nc } \\
\text { pelican1Dsgs-cal.nc } \\
\text { pelican1Esgs-cal.nc } \\
\text { tower1Asgs-cal.nc } \\
\text { tower1Bsgs-cal.nc } \\
\text { tower1Csgs-cal.nc } \\
\text { tower1Dsgs-cal.nc } \\
\text { tower1Esgs-cal.nc } \\
\text { tower1Fsgs-cal.nc } \\
\text { 9421rb-a.nc } \\
\text { 9431rb-a.nc } \\
\text { 9481rb-a.nc } \\
\text { 9491hwl.nc } \\
\text { 9501rb-a.nc } \\
\end{array}$ \\
\hline \multicolumn{6}{|c|}{ Wave measurements } \\
\hline $\begin{array}{l}\text { SBE26 } \\
\text { SBE26 }\end{array}$ & $\begin{array}{l}192 \\
217\end{array}$ & $\begin{array}{l}\text { Pelican } \\
\text { Pelican }\end{array}$ & $\begin{array}{l}\text { 2/29/12 00:34:32 } \\
\text { 7/11/12 16:29:52 }\end{array}$ & $\begin{array}{l}\text { 6/20/12 00:34:34 } \\
\text { 9/6/12 12:29:52 }\end{array}$ & $\begin{array}{l}\text { pelican1Asg-p-cal.nc } \\
\text { pelican1Asg-r-cal.nc } \\
\text { pelican1Bsg-p-cal.nc } \\
\text { pelican1Bsg-r-cal.nc }\end{array}$ \\
\hline SBE26 & 192 & Pelican & 9/6/12 20:22:27 & 12/28/12 00:23:19 & $\begin{array}{l}\text { pelican1Csg-p-cal.nc } \\
\text { pelican1Csg-r-cal.nc }\end{array}$ \\
\hline SBE26 & 217 & Pelican & 2/1/13 22:56:34 & 4/28/13 10:56:06 & $\begin{array}{l}\text { pelican1Dsg-p-cal.nc } \\
\text { pelican1Dsg-r-cal.nc }\end{array}$ \\
\hline SBE26 & 169 & Pelican & 4/28/13 23:36:23 & 7/16/13 19:36:20 & $\begin{array}{l}\text { pelican1Esg-p-cal.nc } \\
\text { pelican1Esg-r-cal.nc }\end{array}$ \\
\hline SBE26+ & 1099 & Tower & 2/16/11 18:54:16 & 7/16/11 13:54:17 & $\begin{array}{l}\text { tower1Asg-p-cal.nc } \\
\text { tower1Asg-r-cal.nc }\end{array}$ \\
\hline SBE26 & 192 & Tower & 7/12/12 1:10:50 & 7/21/12 17:10:51 & $\begin{array}{l}\text { tower1Bsg-p-cal.nc } \\
\text { tower1Bsg-r-cal.nc }\end{array}$ \\
\hline SBE26 & 169 & Tower & 7/21/12 19:59:50 & 9/7/12 15:59:50 & $\begin{array}{l}\text { tower1Csg-p-cal.nc } \\
\text { tower1Csg-r-cal.nc }\end{array}$ \\
\hline SBE26 & 217 & Tower & 9/7/12 21:04:36 & 12/29/12 01:05:26 & $\begin{array}{l}\text { tower1Dsg-p-cal.nc } \\
\text { tower1Dsg-r-cal.nc }\end{array}$ \\
\hline SBE26 & 169 & Tower & 1/31/13 23:54:21 & 4/28/13 07:54:05 & $\begin{array}{l}\text { tower1Esg-p-cal.nc } \\
\text { tower1Esg-r-cal.nc }\end{array}$ \\
\hline
\end{tabular}




\begin{tabular}{cccccc}
\hline Sensor type & Serial number & $\begin{array}{c}\text { Mooring number or site } \\
\text { name }\end{array}$ & Start of data record, UTC & End of data record, UTC \\
\hline & & & Wave measurements - Continued & \\
\hline SBE26 & 192 & Tower & 4/28/13 18:09:34 & $7 / 18 / 13$ 10:09:33 \\
\hline
\end{tabular}



ISSN 2331-1258 (online)

http://dx.doi.org/10.3133/ofr20141246 